MARZENA BOGUS* - CZĘSTOCHOWA

\title{
SZERSZNIK W CIESZYNIE I KLUK W CIECHANOWCU, CZYLI O PIERWSZYCH MUZEACH KSIĘŻYY, A NIE KSIĄŻĄT, NA ZIEMIACH POLSKICH
}

Starałem się [...] dowieść, iż miasto to oraz małe państwo, którego było ono stolicą, godne jest polecenia nie tylko ze względu na swój wiek, lecz przede wszystkim ze względu na ludzi, którzy w dziedzinie uczoności oddali ludzkości ważne usługi ${ }^{1}$

- pisał Leopold Jan Szersznik próbując podnieść rangę Cieszyna i dokonania mieszkających tu osób. Niestety sam autor na dobrą sprawę nie jest znany poza regionem, a Śląsk Cieszyński często pomijany przy omawianiu polskiej historii kultury i oświaty. Problemem zajmują się wybrani naukowcy, często krytykowani za lokalność swoich badań. Obszar warto jednak promować i opisywać, bo był terenem, na którym tworzyli ludzie niewątpliwie przyczyniający się do obecnego stanu kultury polskiej. Natomiast porównanie dwóch placówek - muzeum Leopolda Jana Szersznika i gabinetu Jana Krzysztofa Kluka - pozwoli pokazać jak istotne dla rozwoju kultury są działania pojedynczych osób nawet z niewielkimi możliwościami materialnymi. Za takim wyborem przemawia również cel tworzenia kolekcji i podobny status ekonomiczny założycieli. W temacie artykułu, założono opis pierwszych muzeów księży (rzadko przywoływanych), a nie książąt (czy księżnych), których nazwiska uwzględniają wszystkie leksykony muzeologiczne, toteż tekst nie ma ambicji porównywania powstających ówcześnie na ziemiach polskich placówek możnych. Trudno bowiem zestawić ekskluzywne arystokratyczne zbiory Anny Jabłonowskiej, Izabeli Czartoryskiej, Stanisława Kostki Po-

* Marzena Bogus - dr pedagogiki; adiunkt w Instytucie Sztuk Pięknych Akademii im. Jana Długosza w Częstochowie; e-mail: m.bogus@ajd.czest.pl

${ }^{1}$ L.J. Scherschnik, Nachrichten von Schriftstellern und Künstlern in den Teschner Fürstenthum, Teschen 1810, s. XV, cyt za: G. Chromik, Niemieckie rękopisy i druki ks. Leopolda Jana Szersznika w zbiorach Ksiąznicy Cieszyńskiej, w: Ks. Leopold Jan Szersznik znany i nieznany, red. H. Łaskarzewska, A. Bad'urová, Cieszyn 1998, s. 119. 
tockiego ${ }^{2}$, czy inne kolekcje członków rodzin Lubomirskich, Dzieduszyckich, Baworowskich, Branickich, Raczyńskich, Zamoyskich, Krasińskich, Tyszkiewiczów, Działyńskich i innych ${ }^{3}$, z eksponatami gromadzonymi przez Szersznika czy Kluka. Za zbiorami wspomnianych duchownych, nie stało przecież potężne zaplecze kapitałowe. Mimo niewielkich możliwości finansowych, tworzyli swoje gabinety pełne osobliwości i kuriozów, selekcjonując je i nadając im porządek. Ustalali kryteria doboru obiektów, gromadząc często nie te przedmioty, których najbardziej pragnęli, lecz te, na które było ich stać ${ }^{4}$. Podobne gabinety, których w nowożytnej Europie były tysiące ${ }^{5}$, wyznaczały tendencje kolekcjonerskie i określone zachowania zbieraczy. Nie inaczej było w wypadku naszych „hobbystów”, tworzących zbiory często nazywane „encyklopedycznymi gabinetami osobliwości”, w których przedmioty sztuki i natury koegzystowały ze sobą, tworząc jedną, zorientowaną uniwersalistycznie całość 6 .

Muzeum Szersznika i zbiory Kluka łączy nie tylko usytuowanie placówek $\mathrm{w}$ miastach, których nazwy rozpoczynają się od tej samej sylaby, łączy epoka w której żyli, pasja, nauka oraz posługa duchowa i społeczna. Duchownych w linii prostej dzieliło ponad 400 kilometrów oraz inny, społeczny i polityczny układ związany z przynależnością do różnych państw. Chociaż Szersznik i Kluk nigdy się nie spotkali, to warto zestawić te postaci.

Pełne biogramy bohaterów, niemal rówieśników, można odnaleźć w rozprawach szczegółowych ${ }^{7}$, tu dodajmy, że obaj byli duchownymi i obydwaj gromadzili skarby, które służyły do pogłębiania wiedzy, zwłaszcza historycznej i przyrodniczej. W istocie stworzone przez nich placówki były muzeami uczonych, którzy żyjąc i działając na prowincji oraz dysponując ograniczonymi środkami finanso-

${ }^{2}$ Ze względu na teren oraz daty w których powstawały lub zostały udostępnione wspomniane muzea, w przypadku L.J. Szersznika nie mogą być one traktowane jako wzór do naśladowania.

${ }^{3}$ Literatura oraz przegląd mód, trendów i praktyk muzealnych, zob. Wprowadzenie, w: Miłośnictwo rzeczy. Studia z historii kolekcjonerstwa na ziemiach polskich $w$ XIX wieku, red. K. Kłudkiewicz, M. Mencfel, Warszawa 2014, s. 9-22; o kolekcjonerstwie arystokracji K. Kłudkiewicz, Rodzinna tradycja, romantyczne zobowiazania i indywidualne koncepcje. Uwagi o kolekcjonerstwie arystokracji $w$ Wielkopolsce $w$ drugiej połowie XIX wieku, w: Miłośnictwo rzeczy, s. 187-226, a także G.P. Bąbiak, Sobie, ojczyźnie czy potomności... Wybrane problemy mecenatu kulturalnego elit na ziemiach polskich $w$ XIX wieku, Warszawa 2010.

${ }^{4}$ Więcej na ten temat, zob. M. Mencfel, Skarbce natury i sztuki. Prywatne gabinety osobliwości, kolekcje sztuki i naturaliów na Śląsku w wieku XVII i XVIII, Warszawa 2010, s. 9.

${ }^{5}$ Tamże, s. 18.

${ }^{6}$ Tamże, s. 35, 41.

${ }^{7}$ J. Spyra, Leopold Johann Scherschnik (1747-1814), „Oberschlesisches Jahrbuch“, 7 (1991) s. 91-110; Ks. Leopold Jan Szersznik znany i nieznany, red. H. Łaskarzewska, A. Bad'urová, Cieszyn 1998; J. Spyra, Leopold Jan Szersznik - nauczyciel, kolekcjoner, uczony, w: Malo invidiam quam misericordiam. Wybór pism i dokumentów dotyczacych. Leopolda Jana Szersznika, wyd. J. Spyra, G. Chromik, Cieszyn 2014; Z. Wójcik, Ksiądz Jan Krzysztof Kluk-pisarz i uczony, Ciechanowiec 2012; Z. Wójcik, Nowa biografia ks. Jana Krzysztofa Kluka, proboszcza ciechanowieckiego, w: Anna ks. Jabłonowska i ks. Krzysztof Kluk - ludzie, którzy wyprzedzili swoją epoke, red. N.D. Tomaszewski, Ciechanowiec 2011. 
wymi, starali się stworzyć miejsca obrazujące stan „nowej” wiedzy, opartej na samodzielnych badaniach i poszukiwaniach.

\section{Dlaczego muzeum - jakie muzeum?}

Wprowadzając do opisu zbiorów obu duchownych, krótko przypomnijmy, że na początku XIX w. z entuzjazmem zakładano muzea w całej Europie, choć na ziemiach polskich ze względu na warunki polityczne było to utrudnione. W niniejszym artykule mającym za cel porównanie osobliwości zbieranych przez Szersznika i Kluka, brakuje miejsca by nakreślić tło powstawania kolekcji światowych czy nawet krajowych ${ }^{8}$, choćby tylko począwszy od XVIII w., bo te ,bezpłodne zbytki"9 zagościły w skarbcach szlacheckich i kunstkamerach magnackich dużo wcześniej i opisywane są według różnych kategorii. Trzeba jednak przypomnieć, że idea doboru zbiorów czy grupowania tychże według określonych kryteriów jeszcze na początku XIX w., potrafiła być zaskakująca ${ }^{10}$. Także w kolekcjach Szersznika i Kluka, naturalia mieszały się z artificialiami i trudno jednoznacznie znaleźć klucz gromadzenia eksponatów. Badacze tematu klasyfikują takie placówki w różny sposób ${ }^{11}$. W wypadku Kluka i Szersznika należałoby uzupełnić podział o jeszcze jedną kategorię: muzea szkolne, którym daleko do tych uniwersyteckich czy muzeów nauki ${ }^{12}$, ale ich znaczenie było równie ważne.

\section{Kim byli założyciele?}

Portretując, a właściwie szkicując postaci wspomnianych dwóch duchownych można odesłać do atrybutów na ich pomnikach. Kluk w Ciechanowcu w sutannie z togą akademicką i rośliną w ręku, Szersznik w Cieszynie również w stroju duchownego, ale z książkami w dłoniach - obaj duchowni, obaj uczeni, obaj autorzy dzieł naukowych ${ }^{13}-$ z podobnymi zainteresowaniami, pasjami, a jednak innymi znakami rozpoznawczymi, odmiennymi atrybutami przypisanymi określonym dyscyplinom wiedzy.

${ }^{8}$ Tło historyczne i ideowe zostało uwzględnione w literaturze tematu, zob. Z. Żygulski jun., Muzea na świecie, Warszawa 1982; tenże, Nurt romantyczny w muzealnictwie polskim, w: Romantyzm. Studia nad sztuka drugiej połowy XVIII i wieku XIX, Warszawa 1967, s. 43-55; Muzea polskie, red. D. Folga-Januszewska, Olszanica 2012.

${ }^{9}$ W. Łoziński, Życie polskie w dawnych wiekach, Kraków 1978, s. 37-38.

${ }^{10}$ K. Pomian, Zbieracze i osobliwości. Paryż-Wenecja XVI-XVIII wiek, Lublin 2001, s. 67-88.

${ }^{11}$ Wśród muzeów można wyróżnić klasyfikację na: narodowe i regionalne, kościelne, rezydencjonalne, historyczne, archeologiczne, etnograficzne, uniwersyteckie i nauki, przyrodnicze, krajoznawcze, techniki, etnograficzne, rolnictwa itd. Zob. D. Folga- Januszewska, Muzea narodowe i muzea regionalne w Polsce, w: Muzea polskie, s. 24-55; K.J. Jakubowski, Muzea przyrodnicze, w: Muzea polskie, s. 170- 189; K. Malinowski, Prekursorzy muzeologii polskiej, Poznań 1970, s. 23-58.

${ }^{12}$ E. Wyka, Muzea uniwersyteckie i muzea nauki w Polsce, w: Muzea polskie, s. 156-169. Kolekcje przyrodnicze, które można określić mianem naukowych, powstawały na świecie już w okresie późnego renesansu. Zob. M. Mencfel, Skarbce natury i sztuki, s. 233.

${ }^{13}$ Pomnik Kluka autorstwa Jakuba Tatarkiewicza odsłonięty został już w 1850 r., natomiast Szersznika, którego autorami są Urszula Górnicka-Herma i Tomasz Herma odsłonięto w 2006 r. 
Leopold Jan Szersznik (1747-1814), urodził się w rodzinie urzędniczej, w której przywiązywano wagę do gruntownego wykształcenia ${ }^{14}$. Po okresie nauki $\mathrm{w}$ cieszyńskim gimnazjum, wspomaganej lekturą z prywatnego księgozbioru ojca, przez dwa lata (od 1762 r.) studiował w akademii jezuickiej w Ołomuńcu, a następnie pięć lat w jezuickim nowicjacie w kolegiach w Brnie, Březnicy i Pradze. To tu poznawał kolejne języki i doskonalił wiadomości z fizyki, matematyki wyższej, historii (w tym Kościoła), paleografii i innych nauk. Nie omieszkał wykorzystać też możliwości studiowania w bibliotece kolegium św. Klemensa, która wówczas była największym księgozbiorem w Czechach. Po dwuletniej służbie pedagogicznej w gimnazjum w Chebie, w 1771 r. wrócił do Pragi, gdzie skrystalizowały się jego zainteresowania badawcze. Nawiązał kontakty z uczonymi, wywodzącymi się głównie z grona jezuitów, wziął także udział w konkursie historycznym (który wygrał), przesyłając pracę na temat genezy Słowian połabskich. Niestety jego dobrze zapowiadająca się kariera badacza została przerwana w 1773 r. kiedy podjęto decyzję o kasacie zakonu. W Pradze pozostawał jeszcze przez ponad rok, zajmując stanowisko pomocnika bibliotekarza i opracowując pierwszy katalog rękopisów w Klementinie. Ostatecznie do Cieszyna powrócił pod koniec 1775 r. Kilkanaście lat studiów w różnych placówkach, kontakty z ówczesną inteligencją i pasja obcowania $\mathrm{z}$ księgami, nie mogła pozostać bez dalszej pracy nad samorozwojem, nawet $\mathrm{w}$ prowincjonalnym Cieszynie ${ }^{15}$. $\mathrm{Z}$ czasem uzyskał posadę profesora poetyki i retoryki w gimnazjum, a w $1783 \mathrm{r}$. został mianowany dyrektorem konwiktu założonego przez starostę cieszyńskiego, Adama Wacława Paczyńskiego, hrabiego z Tęczyna, i przejął opiekę nad bursą dla uczniów, również nad tą późniejszą, ufundowaną przez barona Karola Cselestę. W $1787 \mathrm{r}$. Szersznik został mianowany prefektem tutejszego gimnazjum katolickiego. Być może ten fakt $\mathrm{w}$ połączeniu $\mathrm{z}$ niespełnionymi aspiracjami naukowymi spowodował, że eksjezuita zaszczepiał młodym wychowankom pasję poszukiwacza lokalnych skarbów, zwłaszcza tych przyrodniczych. W niespełna dwie dekady później, 57-letni Szersznik został nadzorcą szkół elementarnych obwodu cieszyńskiego, wykonując swoją posługę bez wynagrodzenia. Jego społecznikostwo zasługuje na osobne omówienie, $w$ tym miejscu dodajmy tylko, że po pożarze miasta w 1789 r. kierował jego odbudową i należał także krótko do włodarzy Cieszyna. Przez cały czas czynił również starania o poprawę warunków kształcenia swoich podopiecznych (przez pewien okres oddał na ich potrzeby dom przy rynku w Cieszynie, który zakupił z własnych pieniędzy i w którym prowadził pewnego rodzaju prywatny zakład wychowawczy). Próbował również dalej pisać, choć na tę czynność w ciągu dnia nie miał nawet godziny, dlatego jak sam podkreślał $\mathrm{z}$ braku systematycznej pracy był jedynie zbieraczem. Sporadycznie drukowane publikacje zostały omówione przez jego bibliografów: Johanna Jakoba Heinricha

${ }^{14}$ Podstawowe fakty dotyczące życia przytoczone za: J. Spyra, Leopold Jan Szersznik-nauczyciel, kolekcjoner, uczony, w: Malo invidiam quam misericordiam, s. 11-90.

${ }^{15}$ O kontaktach L.J. Szersznika i jego karierze naukowej zob. J. Spyra, Z Cieszyna do Pragi i z powrotem. Naukowa kariera eksjezuity ks. Leopolda Jana Szersznika, w: Historyk i pisarz na prowincji, red. K. Czajkowski, J. Malura, J. Spyra, Ostrava 2015, s. 21-46. 
Czikanna i Albina Heinricha, a jego rękopiśmienna spuścizna wydana została w wspominanej pracy Janusza Spyry i Grzegorza Chromika.

Podsumowując, po powrocie do Cieszyna Szersznik zajmował się wieloma dziedzinami: szkolnictwem, budownictwem, historią, genealogią i geologią, ekonomią i rolnictwem (hodowla świń, drobiu, cieląt), botaniką, biologią i hydrologią, pisał rozprawy naukowe, w tym opracował słownik osobistości - artystów i pisarzy Księstwa Cieszyńskiego, dokonywał też matematycznych, inżynierskich i mierniczych obliczeń, był twórcą podręczników szkolnych, tych wydanych i niewydanych (o rysunku, pomiarach na odległość, zasadach geometrycznych, rysunku). Cała jego praca była świadectwem historycznym epoki i jej oświeceniowych idei, a także naukowej działalności.

Podobnie rzutki w pracy na polu społecznej posługi był nasz drugi bohater - ksiądz Jan Krzysztof Kluk (1739-1796), którego także można określić jako botanika, twórcę ogrodu roślin leczniczych, kartografa, rysownika, autora książek i podręczników, a zarazem kolekcjonera. Ten zbieracz, urodzony na Podlasiu, był synem architekta i budowniczego kościołów ${ }^{16}$. Kluk uczęszczał do szkół w Drohiczynie i Łukowie, a później trafił do seminarium misjonarzy w Warszawie. Prawdopodobnie z powodu skromnego uposażenia ojca, nie podjął kształcenia w jednej ze szkół wyższych w kraju, za to przez dwa lata nauki seminaryjnej miał okazję zetknąć się z zainteresowaniami przyrodniczymi przełożonego szkoły Piotra Hiacynta Śliwickiego. Ciągle obecny był tu również duch zainteresowań pozostawiony przez Krzysztofa Szembeka czy Michała Sołtyka, który był jednym z wybitniejszych kolekcjonerów minerałów i skał.

Kluk wykształcenie zdobywał w szkołach pijarów, a seminarium ukończył w 1763 r. i chociaż później (w 1787 r.) został doktorem nauk wyzwolonych i filozofii w wileńskiej Szkole Głównej Wielkiego Księstwa Litewskiego, nadal pozostawał oddany swoim badaniom przyrodniczym. Ciechanowiecki pleban o tytuł doktorski i członka naukowego stowarzyszenia Szkoły Głównej wystąpił do rektora uczelni $\operatorname{sam}^{17}$, choć jak wspomniano nie miał studiów uniwersyteckich (napisał za to 12 tomów pism przyrodniczo-gospodarskich, dwa podręczniki oraz dwie publikacje treści religijnej). Po ukończeniu seminarium przez cztery lata był kapelanem domowym u Tomasza Ossolińskiego, starosty nurskiego. Dzięki jego wsparciu, w roku 1767 r. otrzymał stanowisko proboszcza, a równocześnie administratora parafii w Winnej. W 1770 r. Kluk opuścił probostwo wińskie, a przyjął ciechanowieckie. To tu za własne pieniądze wybudował drewniany dom, a zarazem dość wygodną plebanię i tu spędził resztę swego życia.

Jako botanik wiedzę z przyrodoznawstwa zdobywał zapewne w bibliotece Kolegium Pijarów w Łukowie, bibliotece Seminarium Duchownego w Warszawie, bibliotece Ossolińskich w Nurze, a być może także w bibliotece ks. Jabłonowskiej w Siemiatyczach, o co jednak badacze się spierają. Jak pisze Jan Parafiniuk,

${ }^{16}$ Podobnie w tym wypadku nie będę umieszczać pełnego biogramu, odsyłając do książki: Z. Wójcik, Ksiądz Jan Krzysztof Kluk - pisarz i uczony, Ciechanowiec 2012. Tu również dotychczasowa literatura tematu.

${ }_{17}$ Z. Wójcik, Nowa biografia ks. Jana Krzysztofa Kluka, proboszcza ciechanowieckiego, w: Anna ks. Jabłonowska i ks. Krzysztof Kluk, s. 259. 
ks. Kluk był najprawdopodobniej pierwszym w Polsce geologiem gospodarczym, łączącym problematykę przyrodniczą $z$ aspektami ekonomicznymi i technicznymi, w celu wypracowania metod zagospodarowania złóż użytecznych surowców mineralnych ${ }^{18}$. Jednak Kluk znany jest równocześnie ze swego pisarstwa na rzecz upowszechniania wiedzy, głównie przyrodniczej, publikował rzeczy popularne typu instruktażowego, przyrodnicze podręczniki szkolne i rozprawy ściśle naukowe. Towarzystwo Ksiąg Elementarnych, z którym współpracował, nisko oceniło jego prace dotyczące rzeczy kopalnych, sądząc że ,w mineralogii bardzo fałszywe i na niczym zasadzone opinie rozsiał" 19 . Należy pamiętać, że wówczas nie było żadnych informacji w języku polskim w dziedzinie górnictwa, zatem jako pierwszy przygotował pracę podnoszącą te problemy. Przez cały czas gromadził również obiekty, które służyły mu do opisów naukowych, mniej natomiast pasjonowało go kolekcjonowanie książek, choć zgromadził własną, podręczną bibliotekę liczącą około 100 tomów ${ }^{20}$. Kluk nie był ściśle związany z procesem kształcenia instytucjonalnego, choć uczył dzieci w szkole przydworskiej ${ }^{21}$, w placówkach parafialnych w Winnej i Ciechanowcu, a podczas wakacji udzielał lekcji historii naturalnej, ale jak pisał Szymon Bielski „nauczał swój lud i oświecał, jakto dobrym życia przykładem, już gorliwością rozsądnych nauk swoich i kazań"22 oraz treścią napisanych podręczników i książek.

$\mathrm{Z}$ tego krótkiego rysu, można wywnioskować, że podobnie jak Szersznik, także Kluk był człowiekiem o wielu zainteresowaniach. I choć w dalszych rozważaniach głównie zwrócimy uwagę na kolekcje muzealne obu duchownych, to należy dodać, że obaj pasjonowali się przyrodą, stanowiącą najważniejszą część ich naukowych zainteresowań. Obaj założyli również ogrody pełne osobliwości, by zastosować zdobytą wiedzę w praktyce, mieli duże przekonanie o wartości pracy naukowej, byli świetnymi obserwatorami i popularyzatorami i zapewne dużo czasu poświęcali na uzupełnianie swojej wiedzy poprzez analizę roślin w dobrze oznaczonych zielnikach. Co znaczące, gromadząc swoje eksponaty, próbowali je opisywać i klasyfikować, mieli również podobne zainteresowania badawcze (nie biorąc pod uwagę historycznych pasji Szersznika). Jak wspomniano Kluk pisał o rzeczach kopalnych, ale także Szersznik miał na swym koncie

${ }^{18}$ J. Parafiniuk, Ekspozycja surowców mineralnych - ,rzeczy kopalnych osobliwie zdatnieyszych" księdza Kluka w Muzeum Rolnictwa w Ciechanowcu, w: Anna ks. Jabłonowska i ks. Krzysztof Kluk, s. 190-191.

${ }^{19}$ Uważa się, że pracę przygotował na podstawie literatury niemieckojęzycznej, zob. A.J. Wójcik, Górnictwo w „Rzeczach kopalnych” ks. Krzysztofa Kluka, w: Anna ks. Jabłonowska i ks. Krzysztof Kluk, s. 241.

${ }^{20}$ Wójcik, Nowa biografia ks. Jana Krzysztofa Kluka, proboszcza ciechanowieckiego, s. 263.

${ }^{21}$ Z. Wójcik, Krzysztofa Kluka projekty zaktadania gabinetów historii naturalnej przy szkołach w Polsce w XVIII w., „Prace Muzeum Ziemi”, 23 (1975) cz. 1, s. 95-111.

${ }^{22}$ Sz. Bielski, Wiadomość o zyciu i pismach X Krzysztofa Kluka, proboszcza ciechanowskiego, w: K. Kluk, Zwierzat domowych i dzikich osobliwie kraiowych, historyi naturalney poczatki i gospodarstwo: potrzebnych i pożytecznych domowych [...]. t. 1. O zwierzętach ssących, Warszawa 1809 , b.n. 
wątek związany z górnictwem ${ }^{23}$. Pasja geologiczno-mineralogiczna doprowadziła obu do poszukiwań odpowiednich okazów i pogłębiania wiedzy na ich temat. Obaj byli więc duchownymi, którzy przeszli nowoczesną edukację (jeden u jezuitów, drugi u pijarów), żyjącymi na prowincji, ale utrzymującymi kontakty z różnymi ośrodkami naukowymi ich państw.

Różnił ich za to język w którym przekazywali swoje spostrzeżenia, Kluk pisał po polsku, choć z gwarą zachodniego Podlasia, Szersznik po niemiecku i łacinie. Różniły ich też zdolności rysunkowe, gdyż Kluk zajmował się też rytowaniem ilustracji do własnych książek ${ }^{24}$, a Szersznik, co prawda o rysunku (technicznym) pisał, to jednak własnych prac nie ozdabiał ${ }^{25}$. Pozostaje do podkreślenia największa różnica dotycząca spełnienia celu i wyboru drogi życiowej: jeden czynny, gorliwie pełniący posługę (proboszcz wiński, ciechanowiecki, kanonik kruszwicki, brzeski, inflancki, a następnie dziekan drohicki), a drugi bez możliwości wypełniania swej duchowej dyspozycji, służbą dobrego, społecznego życia w rodzinnym Cieszynie, łagodzący z przyczyn niezależnych brak możliwości dopełnienia swego powołania.

\section{Jaka misja - jaki cel?}

Maria Popczyk napisała: ,Jest rzeczą oczywistą, iż to nie przypadek rządzi powstaniem konkretnego miejsca dla sztuki "26, parafrazując to zdanie można by powiedzieć: to nie przypadek, że miejsce dla nauki (kolekcji) znalazło się w centrum zainteresowań Szersznika i Kluka. Wieloletnia pasja musiała mieć podatny grunt do wzrastania. Co było przyczyną, że duchowni zdecydowali się przeznaczać dochody i inne środki własne na gromadzenie ksiąg i eksponatów? Czy chodziło o zbieranie dla samej chęci posiadania, po to by po prostu mieć, by spełnić kolekcjonerską próżność, eksponować dowody własnego bogactwa materialnego czy duchowego? Zapewne tak wyglądałoby to w muzeach magnatów, którzy otaczając się wspaniałymi przedmiotami podkreślali swój status. Wydaje się jednak, że u naszych księży przyczyny powstania kolekcji były zupełnie odmienne, bowiem żaden $\mathrm{z}$ nich nie gromadził eksponatów by pasowały np. do wnętrz mieszkalnych.

Idea oświeceniowego muzeum publicznego, zbiorów historyczno-pamiątkarskich nie była obca naszym bohaterom, a starania by stworzone przez nich instytucje służyły także jako zaplecze do badań i forum doświadczeń poznawczych, by pełniły funkcję dydaktyczną, kształciły i wychowywały, stała się nadrzędna. U podstaw tych dwóch muzeów leżała, jak się wydaje, przede wszystkim wiedza i ciekawość poznawcza. Instytucje te były zatem także pewną manifestacją emancypacji oświeceniowego rozumu, tworzyły przestrzeń objętą intencją poglądowości, mającą wspierać edukację, zarówno samych założycieli, jak i ich uczniów

${ }^{23} \mathrm{O}$ węglu kamiennym zachowało się sporo notatek Szersznika, zob. Spyra, Malo invidiam, s. 86.

${ }^{24}$ Wójcik, Ksiądz Jan Krzysztof Kluk - pisarz i uczony, s. 43 oraz 183-184.

${ }^{25}$ L.J. Szersznik, Anleitungr zum Zeichnen. Znany jest właściwie tylko jeden rysunek regału i kilka z powierzchnią ogrodów, zob. G. Chromik, Niemieckie rękopisy i druki, s. 117.

${ }^{26}$ M. Popczyk, Wstęp, w: Muzeum sztuki. Antologia, red. M. Popczyk, Kraków 2005, s. 7. 
w wielu dziedzinach. Chociaż wspomniane kolekcje duchownych, jak większość w ówczesnym czasie, były zbiorem osobliwości (z przewagą naturaliów), bez właściwego porządku i systematyki, to ani twórcy zbiorów cieszyńskich, ani ciechanowieckich nie można zaliczyć do dyletantów ${ }^{27}$. Stworzone przez nich placówki znacznie się różniły (także wielkością kolekcji), ale ich biblioteki i gabinety $\mathrm{z}$ eksponatami naturaliów i wytworów człowieka $\mathrm{z}$ całą pewnością były także miejscem zdobywania wiedzy i praktyki. Elementy dydaktyczno-wychowawcze mocniej eksponowano w muzeum Szersznika. On sam był pragmatykiem, ale zgodnie z oświeceniowym naturalizmem, który odbiegał od dotychczasowego podejścia związanego $\mathrm{z}$ wykształceniem retorycznym, nie chciał nauczać pamięciowo, a według zasady poglądowości, gdzie zarówno wiedza jak i przykład/ogląd miały równoważne znaczenie. Służyć temu miała biblioteka, Naturalien-kabinet i Kunstkabinet. Jak pisał sam Szersznik:

cel jest taki (...) aby młodzieży szkoły łacińskiej udzielano lekcji dla ułatwienia i uzmysłowienia nauk (...) dla publicznego użytku²

Tak u Szersznika jak i Kluka motywem gromadzenia ksiąg i tworów natury był pociąg do wiedzy, chęć poznania, ciekawość świata i możliwość wykorzystania tychże jako pomocy naukowych. Kolekcje miały więc zastosowanie badawcze, edukacyjne, ale i praktyczne (przyrządy matematyczne), miały służyć społeczności, głównie uczniom w szkole, którzy poprzez dotyk poznawali materię, a nauka przyswajana była wszystkimi zmysłami (poglądowe nauczanie). Te muzea, choć trudno jednoznacznie nazwać naukowymi, dawały możliwość doświadczania. W tym miejscu, przywołując motywy powstania wymienionych placówek, należy wyraźnie zaznaczyć, że podkreślaną misję społeczną mocniej eksponował Szersznik. Kluk, choć dzielił się swoimi zbiorami z lokalnymi szkołami ${ }^{29}$, nie był bezpośrednim donatorem, ale to także dzięki zbieranym eksponatom pisał książki, które poszerzały wiedzę (zwłaszcza tę rolniczą), wielu ludzi. Była to zatem motywacja wieloprzyczynowa: dla samorozwoju, dla kształcenia innych, dla użyteczności regionu (kraju). Wydaje się, że Szersznik jako eks-jezuita który nie mógł spełniać bezpośredniej posługi duchowej (nosił tylko honorowy tytuł proboszcza), posiadał większą świadomość roli, którą miało nieść nowoczesne muzeum, chociaż koncepcja obu placówek wiązała się z ówczesnym, aktualnym stanem wiedzy o świecie i pewnym jej modelem. Szersznik, który wyrósł z jezuickiego uprawiania wiedzy erudycyjno-faktograficznej, opierał się więc na wielu źródłach historycznych, literackich ale także przyrodniczych, uzupełniając je nowinkami technicznymi, i takież były jego kolekcje. Kluk gromadził zbiory naturaliów i wszelkich okazów przyrodniczych.

${ }^{27}$ Dyletantem nazwał J.K. Kluka Józef Rostafiński, w: Polska w kulturze powszechnej, red. F. Koneczny, cz.2, Kraków 1918, s. 272.

${ }^{28}$ M. Kudělka, Korespondence Leopolda Jana Šeršníka s J.P. Cerronim a J.J. Czikannem, „Slezský sborník", 51 (1953) s. 276.

${ }^{29}$ Wójcik, Ksiądz Jan Krzysztof Kluk, s. 187. Być może eksponaty przekazywał do szkół w Drohiczynie, Wilnie, Białymstoku, zob. Lewandowska, Wójcik, Ks. Jan Krzysztof Kluk i Siemiatycze, w: Anna ks. Jablonowska, s. 135. 
Muzea były wyrazem osobistych fascynacji obu duchownych, ale także pewnymi regionalnymi reprezentantami kultury i nauki, którą należało propagować. Były to placówki z pewnością edukacyjne, a nie tylko kolekcjonerskie i kontemplacyjne. W przypadku Szersznika - także instytucja społeczna, bo jak sam tłumaczył, udostępnienie zbiorów było wyrazem miłości do Cieszyna. Duchowny był bowiem przekonany, że jego dar przysłuży się rozwojowi miasta, choć jak się okazało później, musiały minąć lata, by doceniono tę inicjatywę.

Kluk, podobnie jak Szersznik był człowiekiem skromnym, ale świadomym rangi oświatowej ogrodów, roślin oraz gabinetów historii naturalnej. Sam tak określał celowość kolekcji:

Spyta się podobno kto, coż za pożytek z zbioru naturalnego gabinetu? Oto wieloraki. Naprzód każda się rzecz na oko widzi, i dostatecznie poznaje. A przy tym: coraz inne mądrzy czynią wynalazki do różnych się pożytków sięgające; zdaje się nam częstokroć, że u nas tych rzeczy nie masz, liści je w gabinecie znajdujemy. Trafia się też, że gospodarującym co dobrego wpadnie; a kiedy w rożnych stronach, i w jednym kraju, róznie się rzeczy nazywają, w gabinecie na oko się pokażą. (...) a do tego zebranych w cudzych krajach kruszców; krajowi naszemu wiele dobrego może wpływać; nie może to bydź, aby ich nasza ziemia nie miała, lecz wieleż jest takich, któreby one znali? Niechby się w gabinetach przypatrzyli, zadziwiliby się, jak wieluby się odezwało, że to i to w ich się znajduje stronie, łatwiej, jak po najobszerniejszych opisaniach. Nakoniec, gabinety są pomocą do coraz ściślejszego dochodzenia porządku systemów; i jak miłe i przyjemne jest przyrodzenia widowisko, tak tu wiele $\mathrm{z}$ niego rozumnie ciekawy najduje skupionego ${ }^{30}$.

Choć jak zaznaczono był proboszczem i autorem książek rolniczo-przyrodniczych, miał także doświadczenie dydaktyczne ${ }^{31}$, toteż nic dziwnego, że apelował, by przy szkołach wojewódzkich zakładać gabinety, by młodzież mogła doświadczać nauki bezpośredniej, poglądowej, na podstawie zebranych eksponatów. Kluk cenił zatem kolekcje dydaktyczne, które służyły edukacji młodzieży będąc wielkim popularyzatorem nauk o ziemi. Opracowania Szersznika w tym zakresie są mniej znane ${ }^{32}$.

Obaj duchowni mieli zatem podobne zamierzenia, podnosić poziom umysłowy przez tworzenie kolekcji (książek i eksponatów). Zajmowali się podobnymi dziedzinami, choć wykonywali inne posługi, za to łączyły ich działania społeczne, naukowe i wychowawcze.

${ }^{30} \mathrm{Kluk}$, Zwierzą domowych, t. 1, s. 21-22.

${ }^{31}$ Jak wspominano był prawdopodobnie nauczycielem domowym oraz w szkołach parafialnych w miejscach gdzie sprawował posługę, zob. J. Rostafiński, Botanika i zoologia dla szkół narodowych pierwszy raz wydane w latach 1785-1789, „Minerwa polska”, 1 (1927) s. 18-33. Jego talent dydaktyczny przejawiał się w tym jak układał podręczniki, jak zestawiał tytuły i obmyślał prezentację treści. Co warto odnotować, Kluk źle odnosił się do ograniczania przez szlachtę warstwom niższym nauki w szkołach. Wójcik, Ksiądz Jan Krzysztof Kluk, s. 149. O podręcznikach i dziełach Kluka, tamże, 162-164.

${ }^{32}$ Więcej M. Makowski, Dorobek Leopolda J. Szersznika $w$ dziedzinie nauk przyrodniczych, w: Ks. Leopold Jan Szersznik, s. 186-188; Spyra, Malo Invidiam, s. 82- 87. 


\section{Jak powstawały zbiory?}

W powstawaniu placówek muzealnych można wyróżnić pewne etapy, które decydują o powodzeniu danego przedsięwzięcia. Za Dorotą Folgą-Januszewską przytoczmy zauważony przez badaczkę rytm: najpierw jest pomysł twórcy kolekcji, później proces realizacji idei czyli kolekcjonowanie i zdobywanie wiedzy, któremu towarzyszy potrzeba dzielenia się informacjami, także poprzez prezentowanie zbiorów, po czym następuje upublicznienie kolekcji, a z czasem przekazanie kolekcji osobie lub instytucji i nadanie regulacji społecznych ${ }^{33}$. Znakomicie w te fazy wpisują się losy placówki założonej przez Leopolda J. Szersznika, która powołana została dzięki oświeceniowej jasności umysłu i motywacjom o charakterze ponadosobistym.

Jak już wspominano, Szersznik który w 1775 r. powrócił do Cieszyna, rok później uzyskał stałą posadę nauczycielską w gimnazjum katolickim, a dekadę później został kierownikiem placówki, i właściwie od początku swojej pracy starał się o utworzenie tu biblioteki, choć trzeba zaznaczyć, że książki zbierał już w praskim okresie swego życia ${ }^{34}$. Niestety brak odpowiednich warunków dla dużego i cennego jak na ówczesne czasy księgozbioru, który chciał przekazać nieodpłatnie szkole i miastu spowodowały, że w 1800 r. odkupił dawny budynek gimnazjalny i wyremontowawszy go, przeznaczył na zbiory biblioteczne, przyrodnicze i techniczne. Od 1801 r., kiedy centralne władze w Wiedniu wyraziły zgodę na utworzenie zbiorów publicznych (pod warunkiem zabezpieczenia finansowego na prowadzenie placówki, na co Szersznik przystał, choć musiał sprzedać w tym celu swoje ogrody) aż do 1807 r. trwało urządzanie muzeum. Natomiast kolekcja do użytku publicznego została udostępniona już w 1802 r. W 1808 r. prefekt przedstawił władzom projekt fundacji, której kształt ostatecznie został zatwierdzony dopiero w dziesięć lat po śmierci darczyńcy ${ }^{35}$. Jak wynika z tych informacji, musiał mieć ogromną motywację do działania na rzecz społeczności, chociaż nie dysponował dużymi możliwościami finansowymi. To racje wypływające $\mathrm{z}$ chęci rozwoju wiedzy i propagowania jej w regionie, sprawiły, że na swoją kolekcję przeznaczał prywatne, skromne przecież środki wynikające z uposażenia.

Szersznik gromadził książki, naturalia ale także wytwory ludzkie, najmniej chyba przywiązując wagę do dzieł sztuki, choć i takie artefakty miał w swojej kolekcji. Przy zdobywaniu nowych obiektów pomagały mu kontakty utrzymywane z intelektualistami spoza Cieszyna i renoma poważnego kolekcjonera. Toteż wiele osób pomagało mu w zdobywaniu eksponatów lub po prostu go nimi obdarowywało. Wiadomo również, że sam wyszukiwał w okolicach minerały czy starożytności. Kolekcjonując książki, przeważnie je kupował lub wymieniał, ale też nieobca była mu benedyktyńska praca, bowiem niekiedy przepisywał całe manu-

${ }^{33}$ Badaczka wymienia jeszcze dalsze etapy, zob. D. Folga-Januszewska, Muzeum: fenomeny $i$ problemy, Kraków 2015, s. 65-66.

${ }^{34}$ Część zbiorów spaliła się podczas pożaru w 1789 r., a ocalały księgozbiór ze względu na niebezpieczeństwo kolejnej pożogi, przechowywany był w nieoświetlonej piwnicy, zob. K. Szelong, Proces ewidencji i opracowania bibliotecznych zbiorów ks. Leopolda Jana Szersznika. Zarys historyczny, „Roczniki Biblioteczne”, 44 (2000) s. 89.

${ }^{35}$ Spyra, Malo Invidiam, s. 16-17, 58-69. 
skrypty. W ten sposób stworzył warsztat użyteczny, a zgromadzone przez prefekta książki to niemal ówczesny kanon lektur człowieka wykształconego, choć jak podkreśla Barbara Bieńkowska traktował je instrumentalnie - jako źródło wiedzy naukowej, zawodowej i ogólnej ${ }^{36}$. Eksponaty były zdobywane na różnej drodze, pierwsze egzemplarze mineralogiczne otrzymał już w 1777 r. od Josefa Wussina, od Josefa H.A. Gallaša zespół skamielin, a kolekcję cennych minerałów od Albina Heinricha. Tuż przed udostępnieniem publicznym kolekcji, Szersznik przeznaczył na zakup duże, prywatne kwoty: w 1801 r. -2.000 florenów na pozyskanie eksponatów mineralogicznych, a 1.000 na różne przyrządy astronomiczne i geometryczne oraz fizykalne ${ }^{37}$. Zatem zamawiał, kupował, poszukiwał, eksplorował, dostawał, a także czynił starania, by pozyskać je od innych instytucji (np. dublety książek).

Wydaje się jednak, że stworzone muzeum nie było dla ówczesnej społeczności lokalnej rodzajem sacrum, nie potrafiła ona w pełni docenić tego gestu. Czy wpływ na taki stan rzeczy mógł mieć czynnik związany z tym, że sam budynek, w którym zgromadzono kolekcję nie był budowlą o charakterze ceremonialnym jak muzea magnackie? Że nie ulokowano go w specjalnym budynku, który na ten cel został wybudowany, że muzeum nie miało otoczenia, parku - nie było oddalone od ulicy, nie miało imponujących schodów z czuwającymi lwami i masywnych drzwi, nie imponowało portykiem ani fasadą zapowiadającą osobliwe miejsce? Można postawić tezę, że lokalna społeczność nie była jeszcze przygotowana na tego typu zdobywanie wiedzy. Nie wydaje się, by Szersznik był traktowany jako kapłan nauki i właściwie do dziś, poza regionem, nie jest wliczany do panteonu oświeceniowych osobistości.

Zbiory Jana Krzysztofa Kluka, były dużo skromniejsze pod względem liczebnym, natomiast w pobliskich Siemiatyczach ${ }^{38}$ pęczniała kolekcja ks. Anny Jabłonowskiej ${ }^{39}$, udostępniana jednak tylko wybranym osobom, choć były to liczne odwiedziny skoro tylko przez dekadę (1782-1792) jej Gabinet Historii Naturalnej zwiedziło około tysiąca osób. Bywał tam również J.K. Kluk, który umiał docenić znaczenie zbiorów Jabłonowskiej. Świadczy o tym chociażby opis jaki daje w jednej ze swoich książek:

Pobudziła mnie ciekawość do widzenia tych osobliwości; zabraniała szukać sposobności nieśmiałość, oglądająca się na podłość (tzw. niższą pozycję społeczną) osoby mojej. Uświadomiona o tym wysokim mię swoim rozkazem uszczęśliwiła, i pozwoliwszy wszystkie naturalnego gabinetu oglądać cieka-

${ }^{36}$ B. Bieńkowska, Leopold Jan Szersznik - fundator biblioteki publicznej w Cieszynie, w: Ks. Leopold Jan Szersznik znany i nieznany, s. 146.

${ }^{37}$ M. Makowski, Zbiory muzealne Leopolda Jana Szersznika, w: 190 lat założenia muzeum i biblioteki Leopolda Jana Szersznika 1802-1992, red. J. Spyra, Cieszyn 1993, s. 54.

${ }^{38}$ Odległość z Ciechanowca do Siemiatycz to niespełna $40 \mathrm{~km}$.

${ }^{39}$ J. Maroszek, Gabinet siemiatycki i zbiory księżnej Anny z Sapiechów Jabłonowskiej, w: Anna ks. Jabłonowska, s. 139-157; I. Arabas, Petersburskie ślady kolekcji Anny ks. Jabłonowskiej z Siemiatycz, tamże, s. 9-27; Z. Wójcik, Siemiatycki gabinet historii naturalnej Anny Jabłonowskiej, w: Księżna Anna z Sapiechów Jabłonowska (1728-1800) w 200 rocznicę zgonu, red. A. Wołek, Z. Wójcik, Siemiatycze 2001, s. 90-133. 
wości, tym samym okazała, że jej dobroć niema postanowionych granic, lecz się na niższych rozlewa ${ }^{40}$.

Trudno dokładnie określić kiedy Kluk zaczął gromadzić swoje eksponaty, ale zespolił kolekcjonerstwo z pasją, która łączyła się z chęcią podniesienia poziomu zarządzania poprzez uczenie o historii naturalnej oraz innymi problemami przyrodniczo-gospodarskimi ${ }^{41}$. Wiadomo, że odwiedził Siemiatycze w celach naukowych przed $1778 \mathrm{r}$. i bywał też w następnym roku, choć jego pasja musiała rozwijać się wcześniej, być może jak u Szersznika jeszcze w szkołach/seminarium, lub po objęciu funkcji kapelana domowego w 1763 r. u Tomasza Ossolińskiego. Zbigniew Wójcik wysuwa tezę, że prawdopodobnie podczas swoich podróży Kluk docierał także do kolekcjonerów wschodniopruskich, którzy posiadali znakomite zbiory przyrodnicze i obszerne biblioteki ${ }^{42}$. Jak wspominano, jego księgozbiór był dość ubogi, a i kolekcja mineralogiczno-przyrodnicza musiała być niewielka, choć tak naprawdę nierozpoznana w sensie ilościowym. Ponieważ nie dysponował środkami finansowymi, które pozwalały na rozrzutność i spełnianie kolekcjonerskich fanaberii (z dochodów z pisarstwa dokładał się do budżetu swojej parafii), pozyskiwał okazy skał czy minerałów w formie upominków, np. był obdarowywany przez gości odwiedzających Ossolińskich. Proboszcz szukał również eksponatów podczas wypraw terenowych ${ }^{43}$. Wiadomo, że swoje zbiory botaniczne gromadził osobiście, o czym wspominał jego przyjaciel - ks. Szymon Bielski, natomiast ogrodowe założenia czynione przez Kluka były ponoć wspierane przez właścicieli Ciechanowca. Podobno wdzięczni czytelnicy jego rozpraw także obdarowywali go okazami i książkami, dopomagali odwiedzający Ciechanowiec nauczyciele z Drohiczyna, Łukowa, Białegostoku, choć w przeważającej części kupował je za honoraria otrzymane z druku swoich dzieł.

\section{Co kolekcjonowano?}

Pod koniec XVIII w. encyklopedyczne zainteresowanie naukami spowodowało, że podział ich na humanistyczne i ścisłe, właściwie nie istniał. Takie podejście tłumaczyło zbieractwo wszystkiego, bez wyszczególniania dziedzin, oraz powodowało ogromną różnorodność zarówno w gromadzonych księgozbiorach jak i w kolekcjach osobliwości. Pewna moda wśród szlachty na prywatne muzea, skutecznie przenosiła się również na inne warstwy społeczne, zwłaszcza na te, którym nieobce było parcie do wiedzy i jej upowszechnianie. Wszelkie przedmioty dociekań rozumu były również elementem pragnień kolekcjonerskich wielu oświeconych księży, w tym Szersznika i Kluka.

Oczywiście wymienieni duchowni, z racji swoich upodobań, w odmienny sposób kładli nacisk na obszar i tematykę gromadzonych eksponatów. Nieporów-

${ }^{40}$ Kluk, Zwierzat domowych i dzikich, t. 1, Warszawa 1779, s. 20-21, cyt. za: Lewandowska, Wójcik, Ks. Jan Krzysztof Kluk i Siemiatycze, s. 129.

${ }^{41}$ Historią naturalną interesował się od młodości, ale pisać mógł po objęciu probostwa w Ciechanowcu, kiedy okoliczności pozwalały na taką pracę, zob. Wójcik, Ksiądz Jan Krzysztof Kluk pisarz i uczony, s. 95.

42 Tamże, s. 23.

${ }^{43}$ Parafiniuk, Ekspozycja surowców mineralnych, s. 189. 
nywalne w sensie liczebnym były także ich kolekcje. Szersznik pod koniec życia zgromadził ponad 12.000 woluminów i około 10.000 różnych eksponatów ${ }^{44}$, natomiast Kluk miał ponad 100 książek, oraz nieokreślone ilościowo zbiory minerałów, skał, obiektów w postaci innych tworów natury. Przypomnijmy, że ciechanowiecki proboszcz gromadził swoje zbiory prawdopodobnie na plebanii, gdzie miał do dyspozycji własną bibliotekę i mały gabinecik, stąd kiedy jego kolekcja rozrastała się, często innym oddawał swoje eksponaty np. wypreparowane zwierzęta.

Jak już wspominano, różne były motywacje do gromadzenia zbiorów, ale chęć udostępniania wiedzy poprzez ogląd można spotkać w całej Europie, gdzie gabinety eksponatów miały być niezbędne dla kształcenia młodzieży ${ }^{45}$. Odbiciem powyższej idei były zbiory Szersznika - baza do badań i doświadczeń poznawczych. W przeznaczonych na eksponaty czterech pomieszczeniach budynku pogimnazjalnego na pierwszym piętrze, dwa zajmowała biblioteka, następnie czytelnia z przyrodniczymi okazami i czwarta sala - kolekcja muzealna - spójne zaplecze naukowe i dydaktyczne, do tego sala na parterze z przedmiotami kunsztu czyli wytworów człowieka. Zbiory biblioteczne obejmowały wszystkie znane dziedziny wiedzy, a sam Szersznik podzielił je na 27 grup tematycznych ${ }^{46}$, natomiast eksponaty, które weszły w skład muzeum to w większości naturalia, które stanowiły $67 \%$ zbiorów całości. Przytoczmy słowa samego założyciela, który o zgromadzonych przedmiotach pisał:

Przy bibliotece (...) mieści się Gabinet historii naturalnej. W 6-ciu olchowych szafach z mosiężnymi okuciami, z których każda zawiera 24 dość dobre obszerne szuflady, znajdują się pozakrajowe skamieliny i różne gatunki skał, uporządkowane według wydanego przez Dr. Reussa podręcznika mineralogicznego. Krajowe znajdują się w innej szafie o 18-tu szufladach, również odpowiednio podzielone ${ }^{47}$. Zwierzęce bogactwo ukazuje tamże około $100 \mathrm{wy}-$ pchanych ptaków i płazów systematycznie sklasyfikowanych. Istnieje także mały zasób czteronożnych zwierząt. W najbliższym czasie nadejdą trafiające

${ }^{44}$ Makowski, Zbiory muzealne, s. 59.

${ }^{45}$ Być może inspiracją było muzeum Athanasiusa Kirchera (1602-1680), którego organizacja zbiorów została zaimplementowana w wielu kolekcjach europejskich, lub gabinet osobliwości w szkole w Halle Augusta Hermanna Franckego (1698), zob. Folga-Januszewska, Muzeum: fenomeny i problemy, s. 31-32.

${ }^{46}$ Bieńkowska, Leopold Jan Szersznik, s. 147.

${ }^{47}$ Należy dodać, że kolekcję minerałów sam Szersznik pogrupował w 52 gatunki w 6 klasach: kruszce - 207 sztuk, ziemie - 96 szt., sole - 52 szt., kamienie - 44 szt., marmury - 9 szt., rogowce - 3 szt., oraz powtarzające się okazy - 14 szt. Wykaz obejmował łącznie 1.404 obiekty. Dodatkowo spis zbioru roślin ujmował 717 eksponatów. Natomiast Albin Heinrich w 1815 r. w protokole przyjęcia zbiorów, w którym wykazano 9.752 eksponaty, wyszczególnił w zbiorze naturaliów 6.562 eksponaty, w tym 4.619 minerałów, 1.279 skorupiaków i muszli, 108 próbek drzew i żywic, 402 wypchane ptaki i zwierzęta oraz 155 innych przedmiotów (jaja, kości itp.). Zbiór numizmatyczny obejmował 1.905 eksponatów, zbiór sztuki i rzemiosła artystycznego 195 eksponatów, a kolekcja maszyn, modeli oraz przyrządów naukowych liczyła 90 przedmiotów (astronomiczne, optyczne, muzyczne, matematyczne, zegary, klepsydry hydrauliczne i do doświadczeń utensylia typu mikroskopy, lupy, teleskopy). Zob. Makowski, Zbiory muzealne, s. 59. 
się w tutejszych wodach wypchane ryby. Do nie gorzej systematycznie uporządkowanych zbiorów należą: 1) naturalne muszle (mięczaki), 2) skamieniałe i zwapniałe muszle, 3) morskie pajęczaki,4) raki, 5) chrząszcze, 6) motyle, 7) ptasie jaja i gniazda. Zbiór roślin uporządkowany według Linneusza zaszufladkowany jest wraz z roślinami krajowymi: 1) liczne rosnące poza krajem żywiczne gatunki drzew, 2) liczne krajowe kory, 3) liczący 100 gatunków zbiór nasion. Obok znajduje się częściowo w szklanych, częściowo w cynowych puszkach przechowywany dział różnych gatunków żywic, barwników i innych aptekarskich środków. Na parterze, w położonym pod biblioteką pokoju przechowywane będą przedmioty kunsztu, jak częściowo przez wyżej wymienionych młodych mechaników, częściowo zaś przez innych kunsztmistrzów sporządzone modele maszyn, 2) geometryczne, astronomiczne i fizykalne przyrządy, 3) Orbis Pictus Komensky'ego w drewnianych figurach wyobrażony, 4) zbiór uzbrojenia i strzelb, 5) różne starożytności i osobliwości, 6) mały zbiór rzymskich i innych monet lub ich odlewów ${ }^{48}$.

Szersznik nie wymienił tu kolekcji obrazów i grafik, choć i na takie artefakty przeznaczał swoje fundusze, np. w 1811 r. kupił zbiór miedziorytów. Wiadomo, że w jego kolekcji znajdowały się niemal wszystkie dziedziny sztuki: malarstwo, rysunek, rzeźba, rzemiosło artystyczne, w tym cenne i rzadkie cztery nakrycia trumienne cechu winiarskiego wykonane $\mathrm{z}$ jedwabiu $\mathrm{z}$ malaturą olejną $\mathrm{z}$ połowy XVII w. ${ }^{49}$ Należy pamiętać, że Szersznik udostępnił publiczności także swój ogród-skansen, gdzie oprócz roślin i drzew znajdowały się także wyeksponowane ruiny klasztoru, nagrobki mnichów ułożone w kształcie piramidy i pozostałości kościoła parafialnego. Niestety ogród musiał sprzedać na sfinansowanie fundacji służącej utrzymaniu biblioteki i zbiorów muzealnych.

Drugi nasz bohater równie mocno związany był z historią naturalną. Krzysztof Jan Kluk prowadził badania terenowe, uprawiał ogród z ziołami, a nawet leczył swoich parafian ${ }^{50}$, oprócz tego przede wszystkim opracowywał poradniki i rozprawy naukowe, a później podręczniki dla szkół. Dotyczyły one zarówno roślin, hodowli zwierząt, jak i rzeczy kopalnych. Jego dorobek pisarski to też W pewien sposób muzeum przyrodnicze, natomiast realne zbiory, które zgromadził były znacznie skromniejsze od szersznikowskich. Wystarczy powiedzieć, że w sensie ilościowym księgozbiór Kluka to zaledwie 2\% cieszyńskiego. Niestety nie umiemy określić liczebności eksponatów mineralogicznych czy zwierzęcych, natomiast Kluk mógł mieć około 1.500 zebranych roślin, bowiem tyle opisał w trzech tomach swojego Dykcjonarza, podobno był to najobszerniejszy zbiór krajowy. O zbiorach pewne rozeznanie dają informacje pochodzące ze wspomnień ks. Szymona Bielskiego:

kolekcję roślin księżnej Jabłonowskiej do gabinetu naturalnego w Siemiatyczach ofiarował (...) Zrobił także kolekcję wszystkich ptasząt krajowych, zdjętą z każdego skórkę wypychając i wiele za śkło osadzając. Zebrał równie

${ }^{48}$ Tamże, s. 56.

${ }^{49}$ Opis cenniejszych dzieł oraz wykaz eksponatów, zob. I. Adamczyk, Kolekcja księdza Leopolda Jana Szersznika w zbiorach sztuki Muzeum Śląska Cieszyńskiego w Cieszynie, w: Towarzystwo Jezusowe na Śląsku Cieszyńskim, red. J. Budniak, K. Mozor, Kraków 2005, s. 235-242.

${ }^{50}$ G. Brzęk, Krzysztof Kluk, Warszawa 1957, s. 54. 
z wielką starannością wszystkie motyle krajowe, co każdego na to patrzącego

i zadziwiało, i do uczenia się historii naturalnej zachęcało ${ }^{51}$.

Wobec informacji, że ponoć posiadał pełną kolekcję ptaków krajowych ${ }^{52}$ i wszystkich motyli krajowych ${ }^{53}$, zastanawia, gdzie mógł przechowywać te eksponaty. Kolekcja K.J. Kluka to także okazy minerałów i skał, z konieczności ograniczone głównie do okazów pochodzących z terenów Podlasia, Litwy. Zapewne były to eksponaty o różnej wartości, ale każdy minerał jest unikalny, niepowtarzalny, inny od pozostałych. Sam Kluk wspominał o diamencie, który na Litwie wybito z krzemienia, ale który „mało co jest lepszy od górnego kryształu”, co wskazuje na kryształ kwarcu, bo jak pisze Jan Parafiniuk w krzemieniach diamenty absolutnie nie mogą się utworzyć. Były to tzw. diamenty marmaroskie, krystaliczna krzemionka. W kolekcji był prawdopodobnie chryzolit, który jako oliwin może występować w głazach narzutowych, a Kluk pisał, że ten z kolei został wybity z kamienia polnego, wspominał też o ciemnych granatach z Litwy. Wymienia również tof, który był kamieniem mażącym palce, a Parafiniuk podaje, że była to kreda jeziorna. W zbiorach proboszcza były też skamieniałości, muszle i fungity (skamieniałe gąbki) pochodzące z Grodzieńszczyzny ${ }^{54}$. Jak pisze Z. Wójcik okazy konkurowały z siemiatyckimi, tyle, że u Kluka był to zbiór krajowy ${ }^{55}$, co jednak wobec pięciu wielkich sal ekspozycyjnych wypełnionych kolekcją księżnej Jabłonowskiej $^{56} \mathrm{i}$ dodatkowych pomieszczeń magazynowych na tzw. dublety i mniej ważne okazy, wydaje się po prostu niemożliwe.

\section{Komu udostępniano?}

Owe rupiecie ${ }^{57}$, które zbierało coraz więcej osób, były jednocześnie środkiem poglądowym. Zarówno Stanisław August jak i cesarz austriacki Józef II (którzy odwiedzili gabinet w Siemiatyczach ${ }^{58}$ ) postulowali o pomnażanie nauk w swoich krajach. Wykształconym duchownym, niezależnie od tego, o co wnioskowali monarchowie, zależało na upowszechnianiu wiedzy, nie tylko wśród możnych/ inteligencji, ale chcieli ułatwić poznawanie świata szerszemu społeczeństwu, w tym mieszczanom czy chłopom.

W przypadku naszych bohaterów różnica wynikająca z wielkości kolekcji powodowała również inny sposób udostępniania zbiorów. Szersznik zabiegał o to, by stworzyć muzeum otwarte, a Kluk otwarcie udostępniał w swych pismach to, co zdążył zaobserwować, doznać i zbadać. Cieszyński prefekt pragnął przekazać

${ }^{51}$ Sz. Bielski, Wiadomości o życiu i pismach, b.n.

${ }^{52}$ F. Pawęski, Polskie muzealnictwo przyrodnicze, Poznań 1970, s. 29. Ta informacja wydaje się być mało prawdopodobna, gdyż sądząc po rozmiarach pomieszczeń na plebanii, nie miałby gdzie trzymać ponad 400 gatunków.

${ }^{53} \mathrm{~W}$ Polsce występuje ponad 3.000 motyli, zatem tablice entomologiczne musiałyby zajmować również sporo miejsca.

${ }^{54}$ Parafiniuk, Ekspozycja surowców mineralnych, s. 189.

${ }^{55}$ Wójcik, Ksiadz Jan Krzysztof Kluk pisarz i uczony, s. 185.

${ }^{56}$ P. Wilkońska, Księżna Jabłonowska wojewodzina bracławska, „Czas”, 232 (1859) s.1.

${ }^{57}$ H. Rzewuski, Pamiatki Soplicy, za: Pawęski, Polskie muzealnictwo przyrodnicze, s. 23.

${ }^{58}$ Pawęski, Polskie muzealnictwo przyrodnicze, s. 26. 
bibliotekę jak i kolekcję eksponatów nie tylko uczniom, ale wszystkim mieszkańcom miasta, zatem nie chciał by jego zbiory miały wymiar sacrum. Eksponaty nie miały być również dowodami bogactwa duchowego czy materialnego, wszyscy na równi mieli korzystać z dóbr jakie zgromadził. Szersznik wcielał w życie oświeceniowe pojmowanie muzeum jako instytucji dla społeczeństwa w Cieszynie, mieście które wielu uważało za prowincję. Należy jasno napisać, że w tworzeniu muzeum powszechnie dostępnego, które było społecznie pożyteczne, a na dodatek pełniło funkcję dydaktyczną, cechował go altruizm i praktyczność, ale też wizjonerstwo, bowiem stworzył instytucję podnoszącą prestiż regionu, której kryterium poznawcze było nadrzędne. Trudno Szersznikowi odmówić też myślenia o estetycznych zasadach ekspozycji zbiorów, które zostały umieszczone w specjalnie przez niego zamówionych szafach, gablotach, pojemnikach itp. Nawet po ponad dwu wiekach księgozbiór Szersznika i niektóre zgromadzone eksponaty to elementy niezmiernie istotne dla kultury regionu.

Także mały gabinet Krzysztofa Jana Kluka uosabiał jeden z najbardziej żywych ideałów tamtego czasu. Na pewno nie pretendował do roli wielkiej kolekcji, z czego zdawał sobie sprawę sam zbieracz. Nie chodziło jednak o ocenę materialną zbiorów, bowiem z perspektywy czasu i dokonań pisarskich poczynionych na podstawie eksponatów, każdy zgromadzony obiekt nabrał charakteru wielce istotnego, niemal historycznego. To równie prowincjonalne jak cieszyńskie, małe prywatne muzeum, niekiedy było udostępniane dla odwiedzających Ciechanowiec i stanowiło atrakcję poznawczą. Eksponaty Kluka nie posiadały dużej wartości, ale to, co dzięki nim napisał, było doniosłe dla społeczności. Obecne muzeum w Ciechanowcu powstało nie na bazie kolekcji proboszcza, ale dzięki temu, że Kluk rozsławił miejscowość pisząc o rolnictwie i hodowli. Zatem muzeum J.K. Kluka było obecne na kartach jego książek z radami jak suszyć okazy, jak je preparować, konserwować i układać systematycznie, bo jak podkreślał:

zbierać mogą wszyscy, a oglądanie gabinetów historii naturalnej to wielka przyjemność i wytchnienie po znojnej pracy ${ }^{59}$.

\section{Co się stało ze zbiorami?}

Posługując się terminem, wykorzystywanym przez Krzysztofa Pomiana w typologii czterech modeli powstawania muzeów publicznych, można napisać, że przekazanie zbiorów L.J. Szersznika miało wiele wspólnego z modelem ewergetycznym (euergetycznym) ${ }^{60}$, związanym z dobroczynnością publiczną jako podstawowym elementem formacji obywatelskiej. Starania Szersznika o przekazanie swoich zbiorów miastu celem ich upublicznienia, czynione już w 1801 r., a zatem jeszcze za życia kolekcjonera, były na tych terenach ciągle nietypowe i wyjątko-

${ }^{59} \mathrm{Kluk}$, Zwierząt domowych, t. 1, s. 15-17.

${ }^{60}$ Euergetyzm (gr. euergesia) - czynić dobro, postępować dobrze. Muzea ewergetyczne zaczęły powstawać w XVI w., np. Muzeum Archeologiczne w Wenecji, które funkcjonowało początkowo jako statuario publico, powstałe z prywatnej donacji w 1523 r.; także Ashmolean Museum założone z prywatnej donacji w 1677 r., i inne. Zob. K. Pomian, Zbieracze i osobliwości, Gdańsk 2012, s. 313-322. 
we. Przejęcie zbiorów nie stanowiło dla władz intratnej propozycji. Szereg pism, które prefekt wystosował do urzędów doprowadziło w styczniu $1801 \mathrm{r}$. do wydania dekretu, a następnie decyzji cesarza Franciszka II Habsburga wyrażającej zgodę na sprzedaż gmachu gimnazjalnego po obniżonej cenie, w zamian za urządzenie biblioteki i gabinetu mineralogicznego ${ }^{61}$. Szersznik musiał jednak zabezpieczyć finansowo zbiory, dlatego sprzedał swoje ogrody wraz ze wszystkimi zabudowaniami i obiektami, oraz przylegające doń łąki. Kilka lat zajęły prefektowi kwestie urządzania muzeum (i budowa nowego gmachu gimnazjalnego), jeszcze w latach 1812-1813, występował o zwrot kosztów związanych z nabyciem regałów bibliotecznych, szaf i żelaznych gablot. Jednocześnie nie ustawał w staraniach związanych z powiększeniem zbiorów bibliotecznych, chcąc pozyskać duplikaty książek $\mathrm{z}$ biblioteki liceum w Ołomuńcu, których ostatecznie jednak nie otrzymał. Testamentem (zaczął go sporządzać już w 1806 r.), który został upubliczniony w lutym 1814 r., cały swój majątek przekazał bibliotece. Na podstawie tego dokumentu ostatecznie sformułowano akt fundacyjny, którego projekt Szersznik przygotował już w październiku 1808 r., jednak z powodu różnych problemów związanych z kwestionowaniem niektórych zapisów przez Gubernium w Brnie, dopiero w 1824 r. na podstawie wspomnianego projektu i testamentu, ustalono ostateczne brzmienie certyfikatu fundacyjnego ${ }^{62}$. To dzięki założonej przez prefekta fundacji zbiory przez ponad 130 lat przetrwały w tym samym budynku, w tym samym układzie ekspozycyjnym. Zaraz po śmierci Szersznika opiekę nad eksponatami przejął magistrat, który udostępniał je w wybrane dni. Od $1815 \mathrm{r}$. aż do $1831 \mathrm{r}$. opiekował się nimi Albin Heinrich, który powiększył zbiory (o 2.000 woluminów i prawie 1.000 obiektów mineralogicznych) i pracował nad ich skatalogowaniem. Kolejni kustosze, choć rekrutowali się z grona nauczycieli, nie dbali specjalnie o zwielokrotnienie zbiorów ${ }^{63}$. Remonty starego budynku pochłaniały ogromne fundusze, których zaczęło brakować na zakup nowości wydawniczych i pod koniec XIX w. zbiory zaczęły stanowić ciążące finansowo dziedzictwo. W $1910 \mathrm{r}$. zaproponowano połączenie kolekcji ze zbiorami Muzeum Miejskiego w Cieszynie, które działało od 1901 r., a w styczniu 1914 r. uchwalono przejęcie zbiorów przez miasto. Pierwsza wojna światowa udaremniła plany przeniesienia eksponatów i pochłonęła cały kapitał Fundacji Szersznika, a do koncepcji połączenia kolekcji powrócono ponownie dopiero w 1934 r. Muzeum Miejskie przejęło wówczas niemal 17.000 książek, rękopisów, map i innych dokumentów (biblioteka znalazła miejsce w stajni Larischów) oraz podobną liczbę eksponatów (obrazy, grafiki, rzeźby, meble, broń, sztandary, zabytki etnograficzne i archeologiczne, zbiory numizmatyczne, pieczęcie, medale, przyrządy fizykalno-astronomiczne i zbiory mineralogiczne $)^{64}$. Od tego momentu zbiory stanowią podstawową, naj-

${ }^{61}$ Spyra, Malo invidiam, s. 58.

${ }^{62}$ Tamże, 68-69.

${ }^{63}$ Więcej: M. Makowski, J. Spyra, K. Szelong, Zbiory i Fundacja Szersznika po 1814 r., w: 190 lat założenia muzeum, s. 81-90.

${ }^{64}$ E. Chwalewik opisując cieszyńskie zbiory, wspomniał o Bibliotece publicznej im. Ks. Leopolda Szersznika i Muzeum im. Leopolda Szersznika, które liczyło ok. 5.000 minerałów, 600 konch, 350 krajowych i zagranicznych ptaków, 800 medali oraz 1.150 monet i okazów sztuki. Zob. 
starszą i najcenniejszą część Muzeum Miejskiego, od 2002 r. Muzeum Śląska Cieszyńskiego. Podczas drugiej wojny światowej większość eksponatów wywieziono, a część odzyskano dopiero w 1962 r. Pozostałe w Cieszynie zbiory w 1945 r. zostały znacjonalizowane, a w 1959 r. księgozbiór wyłączono z całości. Od roku 1994 przechowywany jest w Książnicy Cieszyńskiej. Zbiory historyczne stanowią kolekcję Muzeum Śląska Cieszyńskiego, natomiast mineralogiczne przekazano w latach 60. do Muzeum Geologii Złóż w Gliwicach. W tym czasie, ze względu na zniszczenia okazów z zielników i zbiorów entomologicznych, zdecydowano się je spalić.

Ustalony w 1801 r. status zbiorów publicznych niewątpliwie przyczynił się do tego, że eksponaty nie uległy rozproszeniu. Niestety prywatne kolekcje mają $\mathrm{z}$ reguły krótszy żywot niż zbiory gromadzone przez instytucje ${ }^{65}$ i często zostają rozrzucone lub zdewastowane.

Tak stało się z eksponatami z kolekcji prywatnej K.J. Kluka która, jak podają wszyscy biografowie proboszcza, przeszła na rzecz Anny Jabłonowskiej. Nie wiadomo jednak jakie okazy krajowe otrzymała księżna. Jedynym potwierdzonym zbiorem są arkusze zielnikowe Kluka, które zostały odnalezione w Petersburgu $^{66}$. Spadkobiercy księżnej, Stanisław i Maksymilian Jabłonowscy odsprzedali ekspozycję główną z włączonym zbiorem Kluka. Wywiezione w kwietniu 1802 r. obiekty trafiły do Moskwy, bowiem car Aleksander I kupił kolekcję dla Imperatorskiego Uniwersytetu Moskiewskiego, niestety podczas transportu wiele eksponatów uległo zniszczeniu ${ }^{67}$. Wypadki historyczne spowodowały, że zbiory prawie w całości spłonęły podczas kampanii napoleońskiej, a w opisie ocalałych nie odnotowywano już proweniencji. Pomimo prowadzonych badań ciągle brak wyczerpujących wiadomości o tym, co Kluk przekazał księżnej. Podobno oprócz zielnika miały to być okazy z kolekcji ptaków i motyli krajowych. Nie wiemy również jaką część eksponatów (wypreparowane szkielety zwierząt, zwłaszcza ptaków) oddał szkołom na terenie dekanatu drohiczyńskiego.

Jedyny zapis, to ten z testamentu z 1796 r. w którym czytamy, że wszystkie książki jeszcze za życia rozdał i rozdysponował ${ }^{68}$. Kim byli obdarowani nie wiemy ${ }^{69}$, choć można przypuszczać, że część książek, zwłaszcza swojego autorstwa, przekazał księżnej Jabłonowskiej, jednak w zestawie woluminów wystawionych na sprzedaż z jej księgozbioru w 1803 r. występuje tylko Dykcjonarz roślinny ${ }^{70}$. Kluk część woluminów pozostawił swojemu następcy, ks. Jakubowi Sosnowskiemu, natomiast mapy i grafiki zostały rozproszone jeszcze za życia plebana i praw-

E. Chwalewik, Zbiory Polskie. Archiwa, biblioteki, gabinety, galerje, muzea i inne zbiory pamiatek w ojczyźnie i na obczyźnie, t.1, Warszawa-Kraków 1926, s. 52.

${ }^{65}$ Parafiniuk, Ekspozycja surowców mineralnych, s. 185.

${ }^{66}$ Pawęski, Polskie muzealnictwo przyrodnicze, s. 27.

${ }^{67}$ Arabas, Petersburskie ślady kolekcji, s. 25.

${ }^{68}$ E. Borowski, Znane i nieznane źródla dotyczace ks. Jana Krzysztofa Kluka w zasobach akt Archiwum Diecezjalnego w Drohiczynie, „Analecta. Studia i materiały z dziejów nauki”, 9 (2000) z. 1, s. 28.

${ }^{69}$ Wójcik, Ksiadz Jan Krzysztof Kluk pisarz i uczony, s. 47.

${ }^{70}$ Tamże, s. 131. 
dopodobnie zaginęły, choć niektóre rękopisy i rysunki map przejął ks. Antoni Wadowski, ówczesny superior domu siemiatyckiego misjonarzy ${ }^{71}$.

Zbiory Krzysztofa Kluka nie zachowały się jako kolekcja ciągła, ale przetrwały w jego pismach i w legendzie tej postaci. Od zapomnienia ocalone zostały nie tylko w słowie drukowanym, ale także w żywej myśli, która przybrała formę Muzeum Rolnictwa im. ks. Krzysztofa Kluka w Ciechanowcu.

\section{Podsumowanie}

Ponieważ nie możemy żyć długo na ziemi, pozostawmy po sobie dowody naszego życia ${ }^{72}$

- ta myśl mogłaby stać się mottem podsumowującym ideę tworzenia zbiorów przez obu duchownych (jako muzeum publicznego i ośrodka naukowego związanego z naturą). Naszych kolekcjonerów można określić mianem umysłów ciekawych (curieuse gemüther), czyli ludzi posiadających ogromną pasję pozyskiwania i rozpowszechniania wiedzy. Przedłożyli własne ślady istnienia, ale takie, które były pożyteczne dla społeczności. Wiedzieli, że ,jeśli to, co czynimy nie przynosi ludziom pożytku, niedorzeczna jest sława" "73.

Roztropni i mądrzy, a nade wszystko wizjonersko patrzący w przyszłość, własnymi kolekcjami dookreślili swoją tożsamość ${ }^{74}$ duchownych, przyrodników, twórców ogrodów i pisarzy. Swoimi zbiorami potwierdzali nie tylko własne preferencje naukowe, ale także prądy i idee epoki - zachowywać aby kształcić - nie tylko możnych, ale też szerszą społeczność. Egalitarny charakter zbiorów (Szersznik) i upowszechnianie wiadomości w pismach i poradnikach rolniczych (Kluk) pokazywały ich zaangażowanie w odniesieniu do otoczenia społecznego i kulturowego.

Słowa kluczowe: Oświecenie; L.J. Szersznik; J.K. Kluk; muzeum przyrodnicze; zbiory publiczne; kolekcja naukowa; duchowni; uczeni; Cieszyn; Ciechanowiec

${ }^{71}$ Lewandowska, Wójcik, Ks. Jan Krzysztof Kluk i Siemiatycze, s. 135.

${ }^{72}$ Tę sentencję Szersznik kazał umieścić na srebrnym medalu wręczanym najlepszym gimnazjalistom w dziedzinie nauk przyrodniczych. Pliniusz Starszy: „Quatenus nobis denegatur diu vivere, relinquamus aliquid quo nos vixisse Testemur”, za: M. Makowski, Dorobek Leopolda J. Szersznika, s. 180. Tłumaczenie dosłowne sentencji: „Chociaż odmówiono nam długiego życia, pozostawmy coś, co zaświadczy, że żyliśmy".

${ }^{73}$ Tamże. Napis na rewersie wspomnianego medalu, Phedrus (Fedrus) z Bajek Ezopowych, ks. III. 17.: „Nisi utile est quod facimus, stulta est Gloria”.

${ }^{74}$ Renata Tańczuk proponuje spojrzeć na zbiory jako na obraz tożsamości kolekcjonera, stanowią bowiem odbicie jego zainteresowań, preferencji estetycznych i preferowanych wartości. R. Tańczuk, Kolekcja jako przedmiot biograficzny, za: http://webcache.googleusercontent.com/ search?q=cache:FDvon21Xh3oJ:old.kultart.lnu.edu.ua/Visnyk_Cult-Arts/2007_07/Tanchuk. $\mathrm{pdf}+\& \mathrm{~cd}=1 \& \mathrm{hl}=\mathrm{pl} \& \mathrm{ct}=\mathrm{clnk} \& \mathrm{gl}=\mathrm{pl}$ (dostęp: 08.03.2016). 


\section{BIBLIOGRAFIA}

Adamczyk Irena, Kolekcja księdza Leopolda Jana Szersznika w zbiorach sztuki Muzeum Śląska Cieszyńskiego w Cieszynie, w: Towarzystwo Jezusowe na Śląsku Cieszyńskim, red. J. Budniak, K. Mozor, Kraków 2005, s. 235-242.

Arabas Iwona, Petersburskie ślady kolekcji Anny ks. Jabłonowskiej z Siemiatycz, w: Anna ks. Jabłonowska i ks. Krzysztof Kluk - ludzie, którzy wyprzedzili swoją epokę, red. N.D. Tomaszewski, Ciechanowiec 2011, s. 9-27.

Bąbiak Grzegorz P., Sobie, ojczyźnie czy potomności... Wybrane problemy mecenatu kulturalnego elit na ziemiach polskich w XIX wieku, Warszawa 2010.

Bielski Szymon, Wiadomość o zyciu i pismach X Krzysztofa Kluka, proboszcza ciechanowskiego, w: Kluk Krzysztof, Zwierząt domowych i dzikich osobliwie kraiowych, historyi naturalney początki i gospodarstwo: potrzebnych i pożytecznych domowych [...]. t. 1, O zwierzętach ssących, Warszawa 1809, b.n.

Bieńkowska Barbara, Leopold Jan Szersznik - fundator biblioteki publicznej w Cieszynie, w: Ks. Leopold Jan Szersznik znany i nieznany, red. H. Łaskarzewska, A. Bad'urová, Cieszyn 1998, s. 138-149.

Borowski, Eugeniusz, Znane i nieznane źródła dotyczące ks. Jana Krzysztofa Kluka w zasobach akt Archiwum Diecezjalnego w Drohiczynie, „Analecta. Studia i materiały z dziejów nauki", 9 (2000) z. 1, s. 21-46.

Brzęk Grzegorz, Krzysztof Kluk, Warszawa 1957.

Chromik Grzegorz, Niemieckie rękopisy i druki ks. Leopolda Jana Szersznika w zbiorach Książnicy Cieszyńskiej, w: Ks. Leopold Jan Szersznik znany i nieznany, red. H. Łaskarzewska, A. Bad'urová, Cieszyn 1998, s. 114-121.

Chwalewik Edward, Zbiory Polskie. Archiwa, biblioteki, gabinety, galerje, muzea i inne zbiory pamiątek w ojczyźnie i na obczyźnie, t.1, Warszawa-Kraków 1926.

Folga-Januszewska Dorota, Muzea narodowe i muzea regionalne w Polsce, w: Muzea polskie, red. D. Folga- Januszewska, Olszanica 2012, s. 24-35.

Folga-Januszewska Dorota, Muzeum: fenomeny i problemy, Kraków 2015.

Jakubowski Krzysztof J., Muzea przyrodnicze, w: Muzea polskie, red. D. Folga-Januszewska, Olszanica 2012, s. 170-189.

Kłudkiewicz Kamila, Rodzinna tradycja, romantyczne zobowiązania i indywidualne koncepcje. Uwagi o kolekcjonerstwie arystokracji w Wielkopolsce w drugiej połowie XIX wieku, w: Miłośnictwo rzeczy. Studia z historii kolekcjonerstwa na ziemiach polskich w XIX wieku, red. K. Kłudkiewicz, M. Mencfel, Warszawa 2014, s. 187225.

Ks. Leopold Jan Szersznik znany i nieznany, red. H. Łaskarzewska, A. Bad'urová, Cieszyn 1998.

Kudělka Milan, Korespondence Leopolda Jana Šeršníka s J.P. Cerronim a J.J. Czikannem, „Slezský sborník”, 51 (1953) s. 260-288.

Lewandowska Ewa, Wójcik Zbigniew, Ks. Jan Krzysztof Kluk i Siemiatycze, w: Anna ks. Jabłonowska i ks. Krzysztof Kluk - ludzie, którzy wyprzedzili swoją epokę, red. N.D. Tomaszewski, Ciechanowiec 2011, s. 127-138.

Łoziński Władysław, Życie polskie w dawnych wiekach, Kraków 1978.

Makowski Mariusz, Dorobek Leopolda J. Szersznika w dziedzinie nauk przyrodniczych, w: Ks. Leopold Jan Szersznik znany i nieznany, red. H. Łaskarzewska, A. Bad'urová, Cieszyn 1998, s. 178-189. 
Makowski Mariusz, Spyra Janusz, Szelong Krzysztof, Zbiory i Fundacja Szersznika po 1814 r., w: 190 lat założenia muzeum i biblioteki Leopolda Jana Szersznika 18021992, red. J. Spyra, Cieszyn 1993, s.81-90.

Makowski Mariusz, Zbiory muzealne Leopolda Jana Szersznika, w: 190 lat założenia muzeum i biblioteki Leopolda Jana Szersznika 1802-1992, red. J. Spyra, Cieszyn 1993, s. 53-60.

Malinowski Kazimierz, Prekursorzy muzeologii polskiej, Poznań 1970.

Maroszek Józef, Gabinet siemiatycki i zbiory księżnej Anny z Sapiechów Jabłonowskiej, w: Anna ks. Jabłonowska i ks. Krzysztof Kluk - ludzie, którzy wyprzedzili swoją epokę, red. N.D. Tomaszewski, Ciechanowiec 2011, s. 139-158.

Mencfel Michał, Skarbce natury i sztuki. Prywatne gabinety osobliwości, kolekcje sztuki i naturaliów na Śląsku w wieku XVII i XVIII, Warszawa 2010.

Miłośnictwo rzeczy. Studia z historii kolekcjonerstwa na ziemiach polskich w XIX wieku, red. K. Kłudkiewicz, M. Mencfel, Warszawa 2014.

Muzea polskie, red. D. Folga- Januszewska, Olszanica 2012.

Parafiniuk Jan, Ekspozycja surowców mineralnych - „rzeczy kopalnych osobliwie zdatnieyszych"księdza Kluka w Muzeum Rolnictwa w Ciechanowcu, w: Anna ks. Jabłonowskai ks. Krzysztof Kluk - ludzie, którzy wyprzedzili swoją epokę, red. N.D. Tomaszewski, Ciechanowiec 2011, s. 185-197.

Pawęski Franciszek, Polskie muzealnictwo przyrodnicze, Poznań 1970.

Polska w kulturze powszechnej, red. F. Koneczny, cz. 2, Kraków 1918.

Pomian Krzysztof, Zbieracze i osobliwości. Paryż-Wenecja XVI-XVIII wiek, Lublin 2001.

Popczyk Maria, Wstęp, w: Muzeum sztuki. Antologia, red. M. Popczyk, Kraków 2005, s. 5-42.

Rostafiński Józef, Botanika i zoologia dla szkół narodowych pierwszy raz wydane w latach 1785-1789, ,Minerwa polska”, 1 (1927) s. 18-33.

Scherschnik Leopold Johann, Nachrichten von Schriftstellern und Künstlern in den Teschner Fürstenthum, Teschen 1810.

Spyra Janusz, Leopold Jan Szersznik - nauczyciel, kolekcjoner, uczony, w: Malo invidiam quam misericordiam. Wybór pism i dokumentów dotyczących. Leopolda Jana Szersznika, wyd. J. Spyra, G. Chromik, Cieszyn 2014, s. 11-112.

Spyra Janusz, Leopold Johann Scherschnik (1747-1814), „Oberschlesisches Jahrbuch”, 7 (1991), s. 91-110.

Spyra Janusz, Z Cieszyna do Pragi i z powrotem. Naukowa kariera eksjezuity ks. Leopolda Jana Szersznika, w: Historyk i pisarz na prowincji, red. K. Czajkowski, J. Malura, J. Spyra, Ostrava 2015, s. 21-46.

Szelong Krzysztof, Proces ewidencji i opracowania bibliotecznych zbiorów ks. Leopolda Jana Szersznika. Zarys historyczny, „Roczniki Biblioteczne”, 44 (2000) s. 87-134.

Tańczuk Renata, Kolekcja jako przedmiot biograficzny, http://webcache.googleusercontent. com/search?q=cache:FDvon21Xh3oJ:old.kultart.lnu.edu.ua/Visnyk_Cult-Arts/2007_07/ Tanchuk.pdf $+\& \mathrm{~cd}=1 \& \mathrm{hl}=\mathrm{pl} \& \mathrm{ct}=\mathrm{clnk} \& \mathrm{gl}=\mathrm{pl}(\mathrm{dostęp:} 08.03 .2016)$

Wilkońska Paulina, Księżna Jabłonowska wojewodzina bracławska, „Czas”, 232 (1859) s. 1-2.

Wójcik Andrzej J., Górnictwo w „Rzeczach kopalnych” ks. Krzysztofa Kluka, w: Anna ks. Jabłonowska i ks. Krzysztof Kluk - ludzie, którzy wyprzedzili swoją epokę, red. N.D. Tomaszewski, Ciechanowiec 2011, s. 239-252. 
Wójcik Zbigniew, Krzysztofa Kluka projekty zakładania gabinetów historii naturalnej przy szkołach w Polsce w XVIII w., „Prace Muzeum Ziemi”, 23 (1975) cz. 1, s. 95111.

Wójcik Zbigniew, Ksiądz Jan Krzysztof Kluk - pisarz i uczony, Ciechanowiec 2012.

Wójcik Zbigniew, Nowa biografia ks. Jana Krzysztofa Kluka, proboszcza ciechanowieckiego, w: Anna ks. Jabłonowska i ks. Krzysztof Kluk - ludzie, którzy wyprzedzili swoją epokę, red. N.D. Tomaszewski, Ciechanowiec 2011, s. 253-264.

Wójcik Zbigniew, Siemiatycki gabinet historii naturalnej Anny Jabłonowskiej, w: Księżna Anna z Sapiechów Jabłonowska (1728-1800) w 200 rocznicę zgonu, red. A. Wołek, Z. Wójcik, Siemiatycze 2001, s. 90-123.

Wyka Ewa, Muzea uniwersyteckie i muzea nauki w Polsce, w: Muzea polskie, red. D. Folga-Januszewska, Olszanica 2012, s. 136-169.

Żygulski Zdzisław jun., Muzea na świecie, Warszawa 1982.

Żygulski Zdzisław jun., Nurt romantyczny w muzealnictwie polskim, w: Romantyzm. Studia nad sztuką drugiej połowy XVIII i wieku XIX, Warszawa 1967, s. 43-55.

\section{ZDJECCIA}

(fotografie nr 1, 4-7,9 ze zbiorów Muzeum Śląska Cieszyńskiego w Cieszynie, fotografie nr 2, 3, 8 ze zbiorów Muzeum Rolnictwa im. ks. Krzysztofa Kluka w Ciechanowcu)

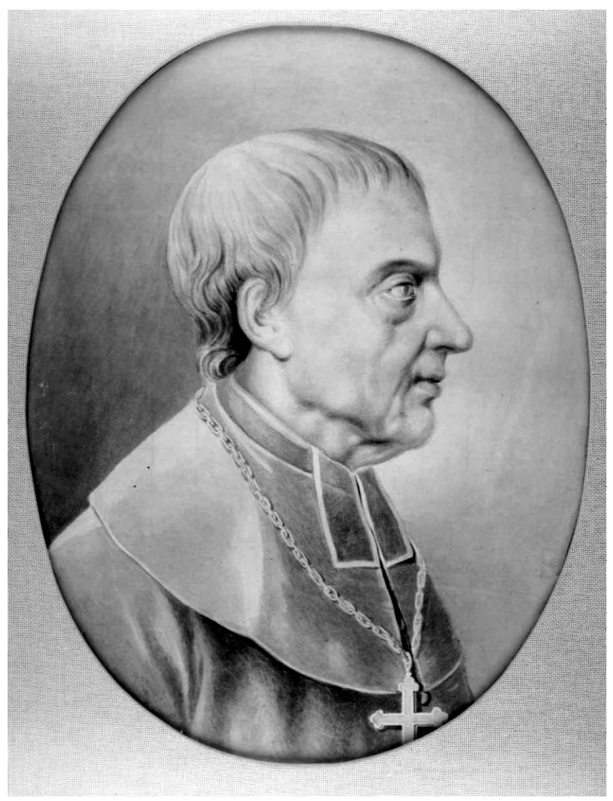

Fot. 1. ks. Leopold Jan Szersznik

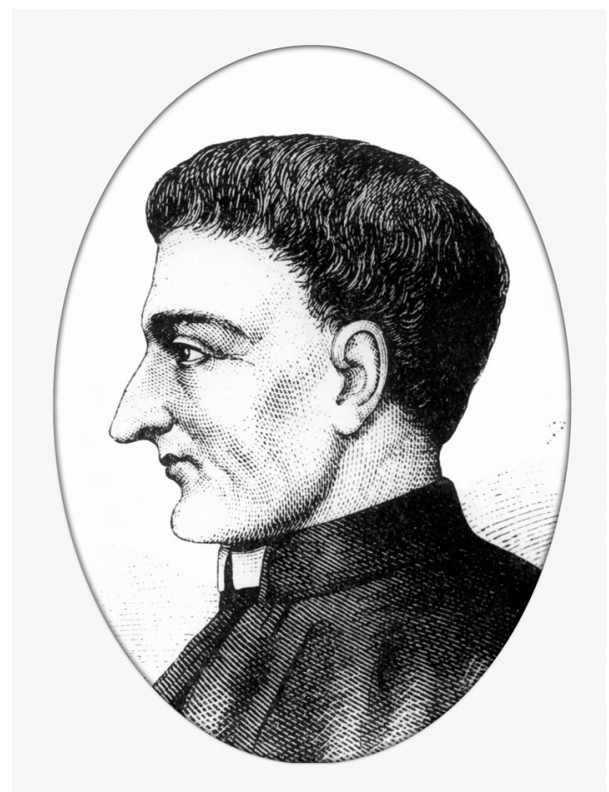

Fot. 2. ks. Jan Krzysztof Kluk 


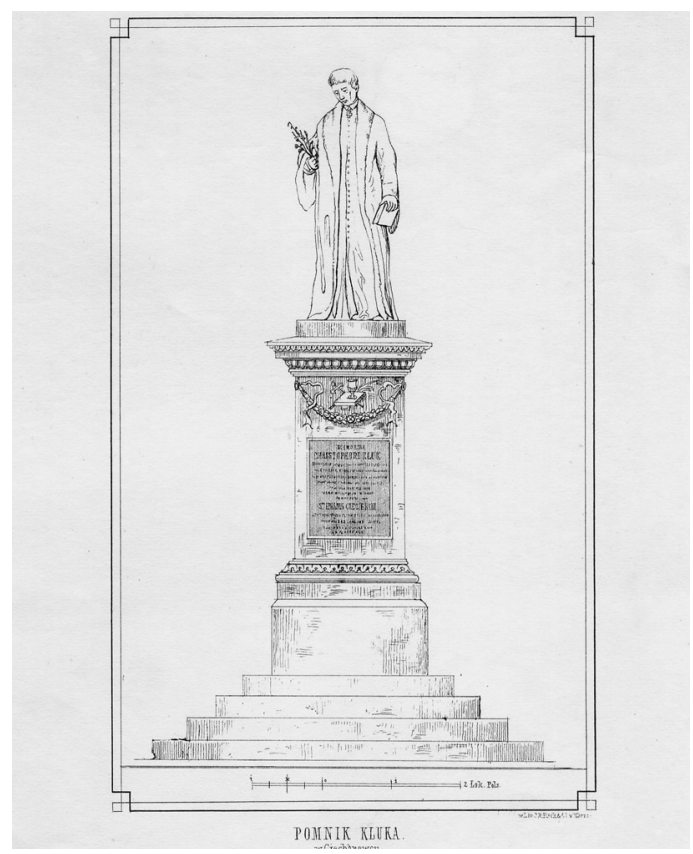

Fot. 3. Pomnik ks. Kluka w Ciechanowcu - litografia 2 poł. XIX w.

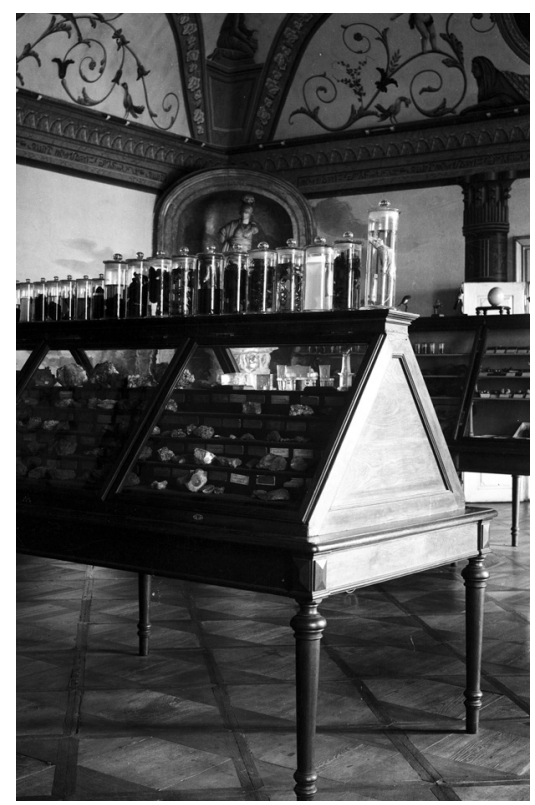

Fot. 4. Gabloty z eksponatami mineralogicznymi L.J. Szersznika w Muzeum w Cieszynie. 


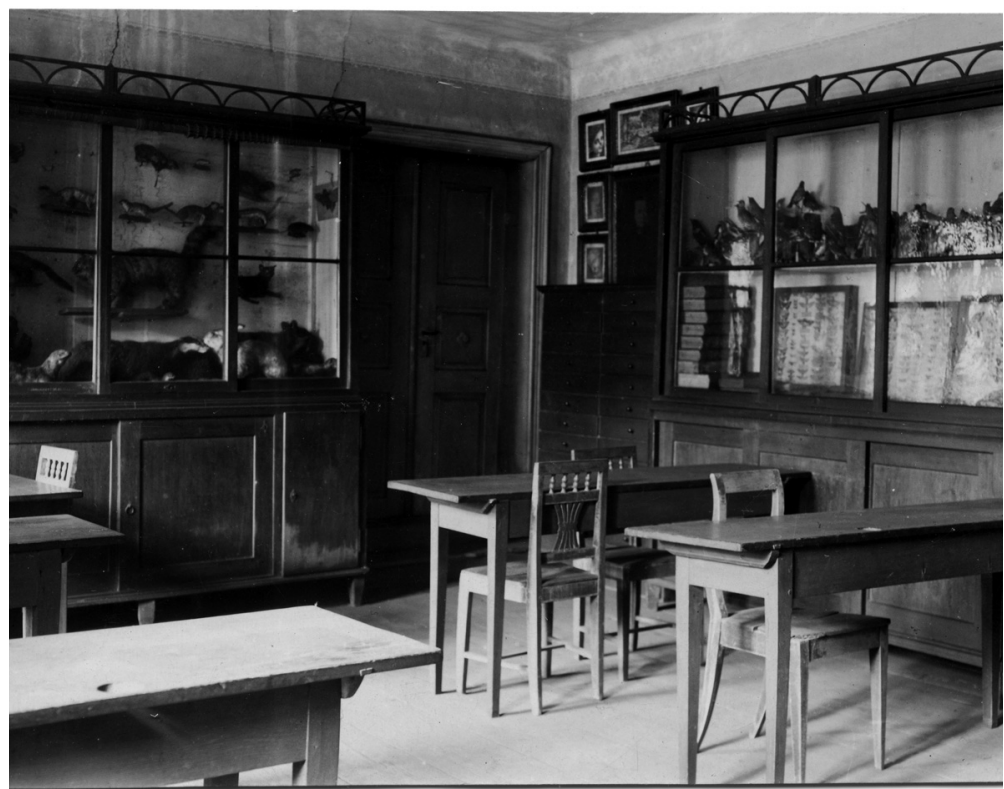

Fot. 5. Wnętrze czytelni i gabloty z eksponatami przyrodniczymi L.J. Szersznika.

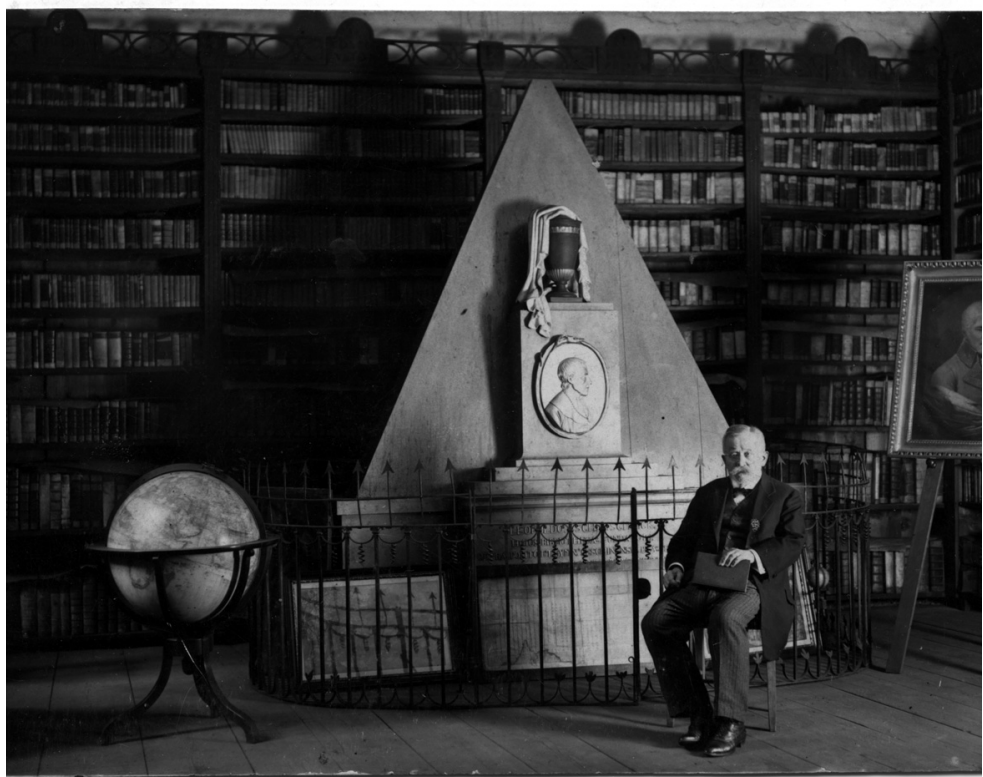

Fot. 6. Kustosz Jan Wytrzens na tle zbiorów bibliotecznych L.J. Szersznika (po 1931 r.) 


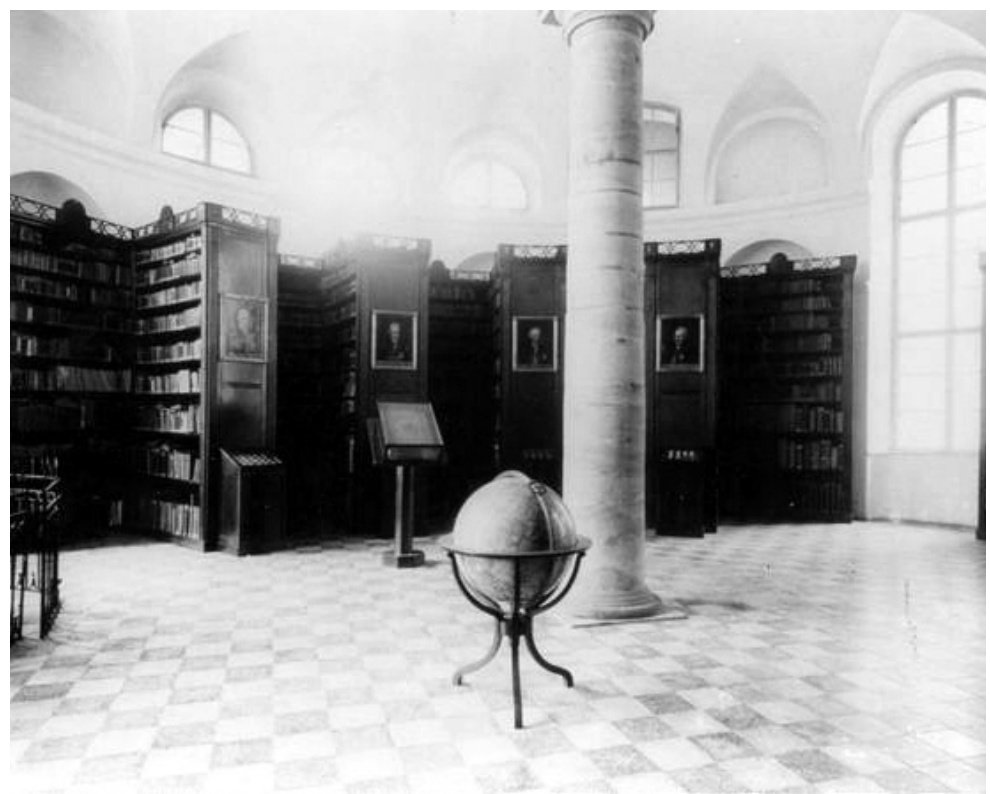

Fot. 7. Biblioteka L.J. Szersznika umieszczona w stajni Larischów (ok. 1935 r.).

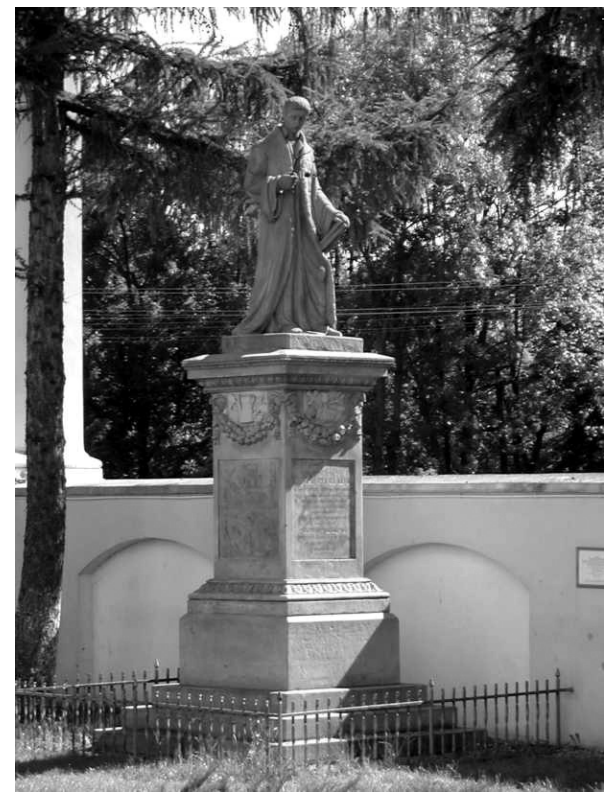

Fot 8. Pomnik ks. K. Kluka w Ciechanowcu.

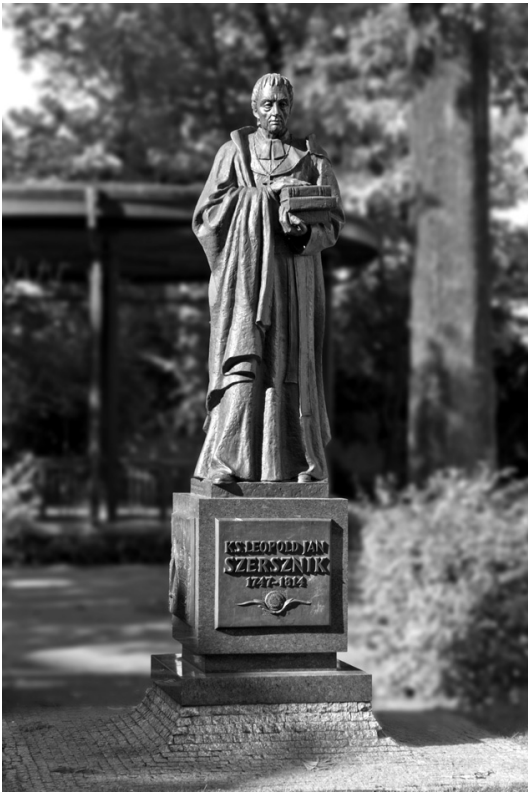

Fot. 9. Pomnik ks. Szersznika w Cieszynie. 


\title{
SZERSZNIK IN CIESZYN AND KLUK IN CIECHANOWIEC. THE FIRST MUSEUMS CREATED BY PRIESTS, NOT DUKES, IN POLISH LANDS
}

\begin{abstract}
Summary
The article aims to compare the museums which belonged to two clergymen: L.J. Szersznik of Cieszyn and J. K. Kluk of Ciechanowiec. Their collections were created on the basis of the Enlightenment ideas which they followed in their lives. Establishing these institutions, the founders were guided by similar aims and intentions as well as similar research interests. They strove to propagate knowledge, especially natural science, by collecting exhibits useful for the study based on observation. In spite of the limited financial resources for exhibits, their collections significantly contributed to satisfying intellectual curiosity. The study shows that the actions of individuals, even if they are in an unfavourable material situation, are important for the development of culture. The aforementioned clergymen and scholars created two institutions, the purpose of which was to promote education by means of observation. The museums which they created, though different in size, were expressions of their personal fascination and certain regional representatives of culture and science, which had to be propagated. The aim of these institutions was not only to collect exhibits but also to educate; both priests had similar intentions: raising people's intellectual level by creating collections (books and exhibits). Szersznik emphasized the social mission more clearly, while Kluk, thanks to his scientific publications, broadened knowledge (especially in agriculture) of many people. They disseminated knowledge not only among educated people but also wanted to show the world to the wider public, including burghers or peasants. Szersznik sought to create an open museum, and Kluk provided in his writings what he had observed and explored.
\end{abstract}

Keywords: the Enlightenment; L.J. Szersznik; J.K. Kluk; a nature museum; public collections; scientific collections; clegrymen; scholars; Cieszyn; Ciechanowiec 